\title{
ATRAVESSANDO O ESPELHO
}

Transfigurando o autor na tradução literária

\section{Ebal Martins Diniz Junior}

NÍVEL: DOUTORADO

Orientador: Prof. Dr. John Milton Área de Lingua Inglesa e Literaturas de Língua Inglesa

UNIVERSIDADE DE SÃO PAULO

FACULDADE DE FILOSOFIA, LETRAS E CIÊNCIAS HUMANAS DEPARTAMENTO DE LETRAS MODERNAS

SÃO PAULO - 2002 
O tradutor literário pode estimular o diálogo entre a tradição literária da obra original e a da língua-alvo. Para essa finalidade, proponho a tradução de autores por intermédio de outros autores.

Tal abordagem revela-se satisfatória por três razões:

(a) a literariedade de uma obra não se perderia invariavelmente num texto denotativo escrito em linguagem padronizada para consumo popular, a menos que fosse essa a intenção do tradutor;

(b) por outro lado, levar-se-ia igualmente em conta o contexto literário da língua-alvo, sem prejuízo das opções estéticas do tradutor e não obstante limitações que lhe fossem impostas pelo mercado;

(c) essa atitude em relação aos paideumas envolvidos permitiria um sem-número de possibilidades tradutórias.

Esta visão não-reducionista e não-prescritiva do processo de tradução literária tenta assim explicitar e desenvolver um aspecto inerente ao ofício do tradutor, pois só se pode efetivamente traduzir literatura a partir dela própria. 
Translating authors through other authors can enable the translator of literature to promote vigorous interaction between the literary tradition of the original and that of the target language.

This approach to translation proves useful for three main reasons:

(a) a work's literariness would no longer be watered down by translators attempting a reader-friendly, contemporary rendering in plain language, unless this is clearly their choice;

(b) the other extreme would likewise be avoided, as both the local literary heritage and the translator's preferences would be relevant, despite the everpresent need to meet editorial demands;

(c) this attitude toward the role of opposing traditions in literary translation would entertain various possibilities.

Thus this nonbinding quasi-manifesto seeks to elucidate literary translation and above all to unveil it as the site where literature begets literature. 
A mamãe 
Vous êtes donc invités à en faire la lecture avec une bienveillante attention et à vous montrer indulgents là où, en dépit de nos efforts d'interprétation, nous pourrions sembler avoir échoué à rendre quelque expression; c'est qu'en effet il n'y a pas d'équivalence entre des choses exprimées originairement en hébreu et leur traduction dans une autre langue; bien plus, si l'on considère la Loi elle-même, les Prophètes et les autres livres, leur traduction diffère considérablement de ce qu'exprime le texte original.

L'Ecclésiatique Prologue du traducteur La Bible de Jérusalem 


\section{Sumário}

Agradecimentos $\quad 7$

Introdução: Alice e o Rei Negro 8

1 A Tradição e a Tradução Individual 11

2 Práxis 39

3 Estudo de Caso 75

Conclusão: Jeito Brasileiro de Traduzir 91

Apêndice: Estudo do Autor-Alvo 94

Bibliografia 104 


\section{Agradecimentos}

Crítica cirúrgica: correta, certeira, minimalista, vivificante-tradução imperfeita de tanto que devo ao John. 


\section{Introdução Alice e o Rei Negro}

'He's dreaming now,' said Tweedledee: 'and what do you think he's dreaming about?'

Alice said, 'Nobody can guess that.'

'Why, about you!' Tweedledee exclaimed, clapping his hands triumphantly. 'And if he left off dreaming about you, where do you suppose you'd be?'

'Where I am now, of course,' said Alice.

'Not you!' Tweedledee retorted contemptuously. 'You'd be nowhere. Why, you're only a sort of thing in his dream!'

'If that there king was to wake,' added Tweedledum, 'you'd go out — bang! — just like a candle!'

\section{Tradução vs. original}

Põe a epifânica revelação do sonho misterioso do rei negro em suspeição a própria identidade de Alice, figura do caráter ambivalente da tradução literária: será sempre dependente do texto original o traduzido? Seus papéis acabam por confundir-se: Quem sonha com quem? Quem iniciou a cadeia sem fim de espelhos que se refletem? Quem por fim subsistirá? Parece-nos infundado o medo da menina. Desapareceria porventura ao acordar o rei negro? Não há-de continuar antes sua simbiose literária? Alice existe, com efeito, em função do rei negro, que lhe confere identidade. Não se trataria, pois, de anular o original, mas de com ele interagir?

Tem por meta o presente estudo incentivar o tradutor literário a adotar postura ativa durante o processo tradutório, assumindo seu papel de criador e mediador entre tradições que 
se completem ou se oponham. Há muito atingiu a dependência excessiva da tradução em relação ao texto original um patamar de pasmaceira cultural e criativa, sobretudo nestes tempos de globalização. Por isso, faz-se necessária uma política consciente de transfiguração explícita do original, um posicionamento capaz de embaralhar os elementos da tradição e alterar-lhe os valores relativos. É preciso acordar o rei negro.

\section{Plano deste trabalho}

Entendo que deva a tradução literária romper com as limitações à forma e ao conteúdo impostas em traduções convencionais. Para isso é mister que avance pela vereda da imitação rumo à recriação num esforço por vezes violento de empréstimo de elementos tanto da forma quanto do conteúdo do original seguido da transfiguração deles numa combinação com tradições literárias locais. Esse paideuma integrá-lo-á e modificá-lo-á a tradução, apresentando seu contributo para a determinação da sensibilidade contemporânea do leitor.

Proponho assim a tradução como canal ideal de diálogo entre tradições literárias. Em vez de demonstrar preocupações quantitativas superficiais envolvendo forma e conteúdo como se independentes fossem, ela pode resgatá-los como facetas interdependentes que apontem uma para a outra num todo integrado e também para temas ou vozes literárias na língua-alvo. Não se trata, porém, de ditar normas arbitrárias e castradoras, mas de resgatar a identidade do tradutor ao sublinhar e valorizar o que já é e faz naturalmente, mesmo que por vezes desconheça a grandiosidade de suas atribuições.

No primeiro capítulo, apresento minha visão do processo de tradução; no seguinte, desenvolvo minha proposta, ilustrando-a com traduções próprias de textos de Lewis Carroll, Mário Quintana e outros. No último capítulo, cerne deste trabalho, sua aplicação é esmiuçada numa versão para o inglês de excertos do conto de Guimarães Rosa "nenhum, nenhuma" por intermédio do James Joyce de Ulysses. Apresenta a conclusão uma leitura dos resultados, abrindo vias para pesquisas na mesma direção.

Ver-se-á, em suma, que o ato tradutório nasce do próprio fazer literário. Menos que método, este pequeno manifesto pretende tão somente elevar no tradutor literário o grau de conscientização do processo em que ele se insere, oferecendo-se como singela homenagem 
aos ilustres desconhecidos que tantas veredas já abriram e ainda podem desbravar para o leitor brasileiro e estrangeiro. 


\section{1 \\ A Tradição e a Tradução Individual}

\section{Metáfrase, paráfrase e imitação}

No que se refere à tradução literária, John Dryden (1631-1700) parece já ter abarcado tudo, segundo nos sugere John Milton em seu trabalho O Poder da Tradução ${ }^{1}$. Poeta e tradutor inglês do século XVII, Dryden classificou as traduções literárias em três categorias: metáfrase, paráfrase e imitação.

Por metáfrase entenda-se a tradução do tipo palavra por palavra, comumente denominada "literal", na qual tem primazia o elemento formal. Na prática é movida pelo desígnio de reproduzir ao máximo o número e a ordem dos vocábulos do original. Um exemplo de metáfrase extrema seria uma tradução interlinear do Novo Testamento em que o texto grego determine até a ordem das palavras na tradução que o acompanha; são não raro necessários junto a elas números, em corpo reduzido, indicativos de sua ordem idiomática na sintaxe inglesa.

Todavia, assim como uma tradução livre pode, para seus críticos, distanciar-se demasiado do original, também a tradução literal com freqüência obscurece o sentido desse original por ignorar diferenças culturais na interpretação de símbolos, por exemplo, e até no próprio estilo, que carrega significado. $\mathrm{O}$ mito de que a melhor tradução seria a mais literal possível encontra-se, porém, enraizado por toda parte e revela, ironicamente, uma visão romântica da tradução como mera transferência de significados.

\footnotetext{
1. $\quad$ Milton, John. O Poder da Tradução. São Paulo, Ars Poética, 1993 (reeditado como Tradução: teoria e prática. São Paulo, Martins Fontes, 1998).
} 
A maioria das traduções, contudo, mesmo as que se classificam como literais, acaba empregando variações do lema explicitado pela New Revised Standard Version da Bíblia: “As literal as possible, as free as necessary". São na verdade paráfrases, pois nelas o sentido precede as palavras exatas do autor na escala de prioridades do tradutor. É o tipo habitual de tradução, em que se preservam aspectos formais que não interfiram na compreensão do significado nem violem convenções gramaticais normalmente aceitas na língua-alvo.

Temos por fim a imitação, em que o chamado texto original eventualmente apenas se vislumbra. Nas traduções de Robert Lowell, por exemplo, acrescentava-se, omitia-se e reordenava-se tudo segundo padrões estéticos próprios, adquirindo assim vida própria o texto traduzido. Tomam-se na imitação grandes liberdades com o original, que se torna, em maior ou menor grau, fonte de idéias a serem aproveitadas pelo tradutor, agora recriador, autor de novo fiat poético cujo resultado, diversamente da criação ex nihilo veterotestamentária, será antes fruto da interação entre a massa original (só aparentemente passiva, mas exercendo resistência constante com suas qualidades e limitações) e suas mãos de artífice.

Imitar não é copiar, mas transformar. Nela pode recriar-se tanto o conteúdo quanto a forma do original. Exemplo do primeiro caso seria a versão "recontada" por Paulo Mendes Campos da alegoria sociológica precursora de todas as narrativas de ficção científica modernas: The Time Machine $e^{2}$. Não obstante as qualidades literárias da obra de H. G. Wells, o que temos em português é uma leitura que, ao atenuar o conflito de classes implícito na relação entre os Elóis (seres humanos idealizados que vivem na superfície da Terra futura) e os Morloques (criaturas horrendas que, morando nas trevas subterrâneas, engordam seus irmãos da superfície para deles depois se alimentarem), conferiu agilidade à narrativa.

Pode também a forma do original ser objeto de imitação, como na tradução da Bíblia levada a cabo por André Chouraqui e mencionada por Henri Meschonnic em críticas a Eugene Nida. Para Meschonnic, não basta transmitir um suposto significado do original; cumpre embeber e recriar sua estrutura formal, o que conferirá à tradução caráter literário. Nida, por sua vez, argumenta que o significado é que importa traduzir, sendo o mais secundário. Parece-me legítima a preocupação com o aspecto formal, já que, possuindo valor alfanumérico, até as próprias letras do alfabeto hebraico podem encerrar significados ocultos.

\footnotetext{
2. Outras obras que também contribuíram para a formação do gênero foram Frankenstein de Mary Shelley, e, é claro, as visões futuristas de Jules Verne.
} 
Tanto é importante aqui a forma que hebraísmos e helenismos da Authorized Version de 1611 passaram a integrar não somente o inglês, mas as demais línguas ocidentais, para as quais o texto bíblico foi vertido de modo ostensivamente "literal". Ocorre que para Nida o texto bíblico é menos literatura que mensagem divina de preocupações estéticas secundárias.

O leitor verá nas próximas seções que nem a tradução livre defendida por Nida nem uma tradução meramente literal são em si suficientes para transpor a riqueza do original para a língua-alvo, constituindo solução esteticamente mais satisfatória almejar a forma aliada ao significado a partir de uma sensibilidade literária.

\section{Tradução livre vs. tradução literal: não basta a tradução livre}

O influente rabino nova-iorquino Joseph Telushkin condena num manual de ética judaica o tabagismo e qualquer atividade que possa causar dano à saúde com base num versículo da Torá assim tradicionalmente vertido do hebraico para a língua inglesa:

"You shall carefully preserve your lives."

(Deuteronomy 4:15)

Cita ainda, além de outras autoridades rabínicas, o próprio Maimônides, para quem

os Sábios proibiram muitas atividades em decorrência do fato de que poderiam representar uma ameaça à vida. Aquele que transgride essas orientações, dizendo: "Arriscarei minha vida, o que os outros têm que ver com isso?" ou "Não me importo com essas coisas" deveria ser castigado com chibatadas por rebeldia.

(Mishneh Torah, "As leis referentes ao assassinato e a proteção da vida humana", 11:5)

Ocorre que este versículo da Bíblia Hebraica (Deut 4:15) sofre um processo exagerado de "contextualização" em praticamente todas as versões atualmente disponíveis. Pode constatar-se uma verdadeira aversão à metáfrase mesmo em versões que adotem o literalismo como essência de sua filosofia de tradução. Comparemos o versículo acima, como transmitido e interpretado pela tradição judaica, com a tradução da New American Standard Bible - 
Updated Edition, versão protestante conservadora que se apresenta como "excepcionalmente literal":

"So watch yourselves carefully."

(NASB-Updated Edition) $^{3}$

Realmente mais literal que qualquer outra tradução moderna, a NASB atenua consideravelmente, entretanto, a força do mandamento ao ignorar o princípio espiritual da preservação da vida ${ }^{4}$. Outra versão de prestígio, a New Revised Standard Version, literal e interdenominacional (a que tem por meta a tradução mais literal possível que seja livre o quanto necessário) assim traduz:

“... take care and watch yourselves closely."

(NRSV)

Tem-se um vislumbre do princípio de autopreservação na Bíblia de Jerusalém, seja na versão inglesa ou na espanhola:

“... be very careful what you do.",

"Tened mucho cuidado de vosotros mismos."

É o caso também da nova edição, revista e corrigida, de La Bible de Jérusalem, de 1998:

"Prenez bien garde à vous-mêmes."

\footnotetext{
3. Na realidade, trata-se apenas da primeira parte do versículo. A segunda, uma admoestação contra a idolatria, não sofre alterações relevantes nas várias versões consultadas.

4. Maimônides (1135-1204), rabino espanhol já citado, compilou e sistematizou um total de 613 mandamentos, entre positivos e negativos, na Torá (o Pentateuco, ou seja, os cinco livros tradicionalmente atribuídos a Moisés). Os textos são esquadrinhados em busca de princípios que fundamentem cada mandamento.
} 
As traduções de maior vendagem hoje no mundo anglo-saxônico, a livre New International Version ${ }^{6}$ e a literal King James Version, optam ambas por uma tradução contextualizada:

“... watch yourselves very carefully."

"Take ye therefore good heed unto yourselves."

$(\mathrm{KJV})$

Alguém poderia argumentar que as versões da Bíblia citadas são todas cristãs e, portanto, ignorantes da herança hermenêutica judaica. Acontece que a referida tendência a privilegiar traduções fluentes pode verificar-se até na nova versão da Torá publicada pela Jewish Publication Society em 19997:

"For your own sake, therefore, be most careful..."

O problema é que yourselves e equivalentes nas versões acima traduzem o termo hebraico nephesh. Presente 754 vezes nas Escrituras Hebraicas, aqui e em 242 outras passagens tem o sentido de "ser humano sujeito à morte, da qual pode ser salvo e ter a vida prolongada". 8

Constatamos que a versão verdadeiramente literal citada pelo rabino Telushkin é a que melhor representa as sutilezas do original conservadas na tradição judaica:

"You shall carefully preserve your lives."

\footnotetext{
5. Traduz, porém, o versículo 9 assim: "But take care, as you value your lives!"

6. Resultado do esforço conjunto de 115 tradutores de diversas igrejas evangélicas, busca "a balance between word-for-word and thought-for-thought."

7. The Torah: the five books of Moses. Philadelphia, Jewish Publication Society, 1999.

8. Dados coletados de um levantamento exaustivo de cada uma das passagens, acompanhado das respectivas traduções na King James Version, disponível em The E. W. Bullinger Companion Bible. Grand Rapids, Zondervan Bible Publishers, 1974.
} 
Vemos que uma tradução livre, por si só, não significa necessariamente uma boa tradução, não obstante a tendência moderna a desprezar metáfrases e a buscar paráfrases unicamente com a literalidade aceitável idiomaticamente.

\section{Tradução livre vs. tradução literal: não basta a tradução literal}

A literalidade tampouco se mostra suficiente em si mesma para abarcar o fenômeno literário, mesmo que se priorize o sentido. O versículo 9 do capítulo 11 do Evangelho de Lucas, por exemplo, costuma gerar traduções semelhantes à da New Revised Standard Version:

So I say to you, Ask, and it will be given you; search, and you will find; knock, and the door will be opened to you.

Luke 11:9 (NRSV)

que, não obstante quatro séculos de distância, é quase idêntica à da King James Version (Authorized Version):

And I say unto you, Ask, and it shall be given you; seek, and ye shall find; knock, and it shall be opened unto you.

Luke 11:9 (KJV)

Parece um caso de tradução incontroverso. Os problemas surgem, no entanto, quando se examina o contexto imediato. Cristo acaba de contar uma parábola sobre a necessidade de persistência na oração:

And he said to them, "Suppose one of you has a friend, and you go to him at midnight and say to him, 'Friend, lend me three loaves of bread; for a friend of mine has arrived, and I have nothing to set before him.' And he answers from within, 'Do not bother me; the door has already been locked, and my children are with me in bed; I cannot get up and give you anything.' I tell you, even though he will not get up and give him anything because he is his friend, at least because of his persistence he will get up and give him 
whatever he needs.

"So I say to you, Ask, and it will be given you; search, and you will find; knock, and the door will be opened for you..."

Luke 11:5-9 (NRSV)(Grifos acrescentados)

Se a finalidade da parábola é ensinar a persistência na oração, é estranho que sua aplicação, explicitada no versículo 9, pareça apenas estimular o crente a voltar-se para Deus nos momentos de necessidade e pedir aquilo de que precisa. Examinemos o original grego da frase Ask, and it will be given you:

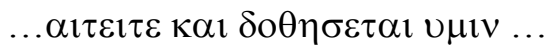

Segundo Charles B. Williams (The New Testament: a translation, citado em The Amplified Bible, Zondervan), o imperativo presente afirmativo ( $\alpha \imath \tau \varepsilon \imath \tau \varepsilon$, do verbo $\alpha \imath \tau \varepsilon \omega)$ no grego koiné com freqüência indica ação continuada ou repetida. Tanto W. C. Taylor quanto Isidro Pereira traduzem $\alpha \imath \tau \varepsilon \omega$ como "peço, rogo", além de Fritz Rienecker e F. Wilbur Gingrich $^{9}$. O mesmo verbo emprega-se quando alguém se dirige a um superior, o que sugere súplica e persistência no pedido.

Tudo parece indicar que uma tradução mais satisfatória da passagem seria semelhante à da New Living Translation, paradoxalmente uma das mais livres:

"And so I tell you, keep on asking, and you will be given what you ask for. Keep on looking, and you will find. Keep on knocking, and the door will be opened."

Luke 11:9 (NLT)(Grifos acrescentados)

Este é apenas um exemplo de como uma tradução "palavra por palavra" pode não necessariamente representar a melhor opção para o tradutor.

\footnotetext{
Veja a bibliografia para as referências completas.
} 


\section{Tradução livre vs. tradução literal: a questão da fidelidade na tradução}

Um paradoxo. É expondo um paradoxo que Jorge Luis Borges inicia em 1971 um seminário sobre tradução na Columbia University. Há, segundo o escritor argentino, dois modos legítimos de traduzir: a tradução literal e a recriação. Ao ser literal na tradução do título de As Mil e Uma Noites, originalmente escrito em árabe corrente, o capitão Burton paradoxalmente provocou um estranhamento de certa beleza: The Book of the Thousand Nights and a Night. Já Chaucer preferiu recriar a sentença latina "Ars longa, vita brevis" enriquecendo a musicalidade do original com o acréscimo de um verbo: "The lyf so short, the craft so long to lerne".

Aceite embora ambas as técnicas, Borges prossegue:

If I may speak of my own work, when I am being more or less straightforward in my expression, then I think the translator has the right to rephrase what I've done. ${ }^{10}$

Suas observações parecem trair uma certa desconfiança em relação ao tradutor. Nas passagens mais livres ele poderia "recriar" o original (adaptá-lo às convenções gramaticais da prosa corrente); nos trechos estilisticamente mais sofisticados, no entanto, o tradutor deveria aproximar-se o quanto fosse possível do original. Dois pesos, duas medidas?

O próprio Borges, porém, preferiu uma dicção anglo-saxônica na tradução de sua obra a um cômodo literalismo:

Simplify me. Modify me. Make me stark. My language often embarrasses me. It's too youthful, too Latinate. I love Anglo-Saxon. I want the wiry minimal sound. I want monosyllables. I want the power of Cynewulf, Beowulf, Bede. Make me macho and gaucho and skinny. ${ }^{11}$

Criticando uma de suas traduções para o inglês:

\footnotetext{
$\overline{10 .}$ GIOVANNI, Norman, HALPERn, Daniel e MACSHANE, Frank (eds.). Borges on writing. New York, The Ecco Press, 1994, p. 104.

11. Citado em $O$ poder da tradução, p. 139.
} 
Instead of a "dark room" for "una habitación oscura," you get "an obscure habitation." 12

E ao examinarmos os exemplos que Borges fornece, torna-se evidente a superioridade da estratégia de recriação sobre a tradução literal. Enquanto esta implicitamente caminha para a saturação típica das transgressões gratuitas, a recriação visa, inclusive com o conveniente uso do literalismo, a um todo artístico.

Borges não é o único fascinado pelo ideal heróico. Seamus Heaney confessa ter Beowulf entranhado em seu próprio estilo. Quando Borges pede a transfiguração de seu texto, pretende introduzi-lo na linhagem inglesa de Gerard Manley Hopkins e outros que cederam aos encantos do poema épico. Trata-se de uma efetiva inserção numa tradição literária alheia por meio da tradução!

É ainda de intrigar que Borges tenha considerado tanto a tradução literal, como ele a chama, quanto a recriação, que não constitui exatamente uma tradução livre, "modos legítimos de tradução". Conclui-se que, para o escritor argentino, não haveria traduções definitivas ou mesmo modos únicos de traduzir.

De fato, a tradução perfeita não seria desejável. Em The Oval Portrait, Edgar Allan Poe (1809-1849) narra os esforços de um pintor para retratar sua amada, que possui as características da própria vida:

...And in sooth some who beheld the portrait spoke of its resemblance in low words, as of a mighty marvel, and a proof not less of the power of the painter than of his deep love for her whom he depicted so surpassingly well. But at length, as the labor drew nearer to its conclusion, there were admitted none into the turret; for the painter had grown wild with the ardor of his work, and turned his eyes from the canvas rarely, even to regard the countenance of his wife. And he would not see that the tints which he spread upon the canvas were drawn from the cheecks of her who sat beside him. And when many weeks had passed, and but little remained to do, save one brush upon the mouth and one tint upon the eye, the spirit of the lady again flicked up as the flame within the socket of the lamp. And then the brush was given, and then the tint was placed; and, for one moment, the painter stood entranced before the work which he had wrought; but in the next, while he yet gazed, he grew tremulous and very pallid, and aghast, and crying with a loud

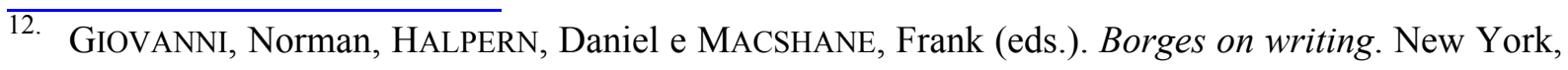


voice, 'This is indeed Life itself!' turned suddenly to regard his beloved:- She was dead!"

Se a tradução e o original forem idênticos, um dos dois será desnecessário. Não se pode defender a tradução única ou definitiva. Na verdade, ela somente seria possível com critérios autoritários e limitadores. A forma, por importante que seja, não constitui o único fator. Tampouco o conteúdo. A inserção da tradução no paideuma local, no entanto, abre o leque de leituras possíveis.

Não basta que a tradução seja uma coleção de pedaços de cadáveres ou um Frankenstein sem alma. A tradução literária é antes como o boi que mastiga o alimento e o engole, regurgitando-o seguidamente. Assim também o mesmo texto pode ter várias traduções válidas. De forma corrosiva e deformadora, por meio de ácidos estomacais variados, a tradução vai revelando a cada refluxo um aspecto nutritivo antes desconhecido e insuspeito do original. Busca-se assim o esgotamento de suas potencialidades estéticas. De certo modo, a própria permanência de uma obra no paideuma universal (no sentido poundiano) dependerá de sua vitalidade - de sua resistência a novas traduções.

No mesmo seminário sobre tradução, Borges comenta o relacionamento com um tradutor seu para a língua inglesa, Norman Thomas di Giovanni, ali presente:

We don't think of ourselves as two men when we are working. We are two minds attempting the same goal. ${ }^{13}$

Borges referia-se a uma colaboração efetiva, mas supõe uma certa identidade de espírito; empresta ao tradutor poderes criativos:

Borges exhorts me to "Fling [the original] aside and be free!" ${ }^{14}$

O autor original chega a transfigurar-se:

DI GIOVANNI: Our sole aim [at the last stage of our work] is to see that the piece reads

The Ecco Press, 1994, p. 132.

13. Ibid., p. 107. 
as though it were written in English. ${ }^{15}$

O tradutor começa com a letra morta de uma tradução metódica, quase automática, para então buscar uma centelha fugidia que confira a seu texto um status literário, o que só ocorrerá se assumir o papel de recriador e, como tal, usar a matéria-prima de que dispuser na língua-alvo, ainda que instintivamente.

Nesse processo, a tradução literal sem função poética evidente é descartada como inferior:

DI GIOVANNI: ... two sentences - or two forms of the same sentence - and this is really my whole textbook on translation. Here is the first form; it is from a story by Borges:

The torrential rains, Captain Liddell Hart comments, caused this delay, an insignificant one, to be sure.

The other form reads:

Captain Liddell Hart comments that this delay, an insignificant one to be sure, was caused by torrential rains.

I would like us to judge this as translation without referring to the original. It's plain that the second form is better. As a matter of fact, it is simply a rewriting of the first. It should be obvious that the elements of the first sentence are put together all wrong. They are not forceful. A good sentence in English has a structure that begins with the second most important element, moves to the least important element, and ends with the strongest element. The pattern is 2-3-1. The second sentence follows this rule. But notice how limp the first sentence is. So my whole thesis on translation is that you must write good sentences-effective English. That's all there is to it. ${ }^{16}$

Pronunciadas na presença de Borges, essas afirmações parecem contar com sua bênção. Comparadas com as duas categorias de tradução literária aceitas por Borges, no

\begin{tabular}{l}
\hline 14. Ibid., p. 114. \\
15. Ibid., p. 116.
\end{tabular} 
entanto, revelam da parte do escritor menos uma identificação com seu tradutor que uma coalizão estratégica. Seu texto precisa pelo menos possuir a concritude anglo-saxônica, já que não é possível (ou mercadologicamente aceitável) um texto atual na voz de Dr. Johnson:

BORGES: If I could write eighteenth-century English, that would be my best performance. But I can't. One can't be Addison or Johnson at will. ${ }^{17}$

Borges refere-se às limitações naturais de sua competência escrita na língua inglesa, limitações essas que, em relação aos elevados padrões desejados pelo escritor, se aplicariam à maioria dos falantes nativos alheios à literatura. Em última análise, Borges na realidade buscava um tradutor que o transfigurasse! É nessa direção que este trabalho tenta traçar seu caminho.

Outro aspecto importante é que há muitas vozes e modos de traduzir. Após a citação desta seção em que seu tradutor defende a fluência no texto traduzido, Borges ressalva:

Of course, there are other possible methods. ${ }^{18}$

Com efeito, essas inúmeras traduções possíveis são para ele diversas perspectivas de un hecho móvil ou, ainda, un largo sorteo experimental de omisiones y de énfasis. ${ }^{19}$ Borges desmistifica assim a tradução, como Poe, em seu ensaio The Philosophy of Composition, a poesia. Ao comparar um trecho em diversas traduções da Odisséia, Borges conclui:

¿Cuál de esas muchas traducciones es fiel?, querrá saber tal vez mi lector. Repito que ninguna o que todas. Si la fidelidad tiene que ser a las imaginaciones de Homero, a los irrecuperables hombres y días que él se representó, ninguna puede serlo para nosotros; todas, para un griego del siglo diez. Si a los propósitos que tuvo, cualquiera de las muchas que trascribí, salvo las literales, que sacan toda su virtud del contraste con hábitos presentes. No es imposible que la versión calmosa de Butler sea la más fiel. ${ }^{20}$

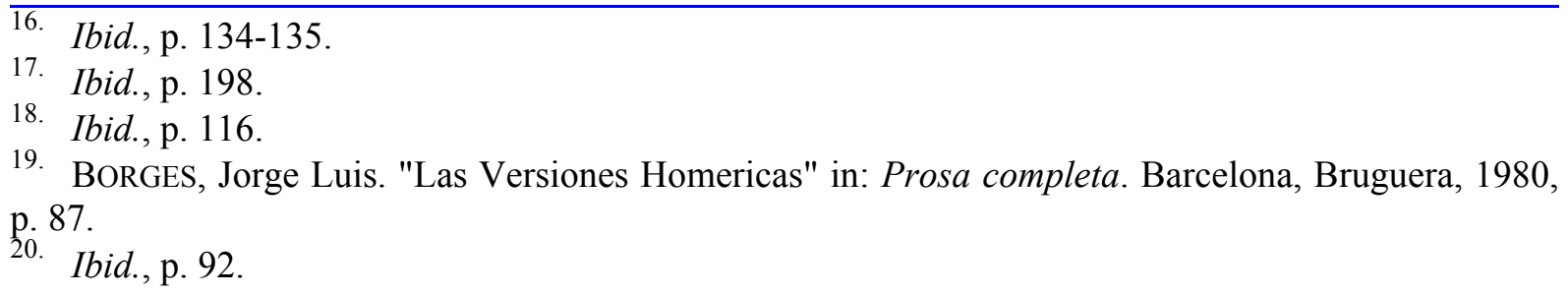


A fidelidade é tanto inatingível quanto indesejável na tradução, pois a interação reclama alteridade. Precisamos de um conceito de tradução literária tal como exemplificado pelas traduções poundianas em geral. Ezra Pound (1885-1972) abalou o pentâmetro iâmbico inglês ao adotar formas poéticas do japonês (haikai) e do provençal (Arnaut Daniel) e recriar poemas chineses em Cathay. Ao reintroduzir, porém, a aliteração na poesia de língua inglesa com sua tradução do Seafarer, poema anglo-saxônico que, no estado em que chegou até nós, representa um embate entre a tradição humanista e a cristã, Pound restaurou o poema a uma provável versão original pagã. Vemos que não se preocupava apenas com a forma.

Schleiermacher já defendera a recriação de "literaturas inteiras" na língua alemã (Übersetzen) como meio de criação e fortalecimento da literatura nacional. Como Goethe, acreditava que a tradução deveria trazer o leitor ao original e não o inverso. Nessa aproximação, contudo, Pound era coerente com um projeto literário e valores próprios, com base nos quais selecionava os aspectos a serem recriados nas traduções que fazia. Chegou a criticar, por exemplo, as inversões sintáticas transpostas do grego para o inglês por Robert Browning, a quem admirava:

“... inversions of sentence order in an uninflected language like English are not, simply and utterly are not any sort of equivalent for inversions and perturbations of order in a language inflected as Greek and Latin are inflected."21

Um literalismo nos moldes apregoados por Schleiermacher pode realmente levar o leitor culto ao autor, mas o argumento de que uma tradução literal seria necessariamente mais fiel ao original que outra mais livre não encontra, a meu ver, respaldo na realidade. Lexicalmente, por exemplo, até itens prosaicos como as cores podem possuir, em culturas distintas, cargas simbólicas diferentes e mesmo opostas. O sentido pode ainda tornar-se mais obscuro em traduções literais que no original se nelas se buscar sistematicamente o estranhamento mediante um aparato formal sofisticado que pretenda corresponder, por exemplo, à estrutura sintática de um original pífio escrito num idioma de estrutura naturalmente muito diversa daquela da língua-alvo e, portanto, potencialmente exótico.

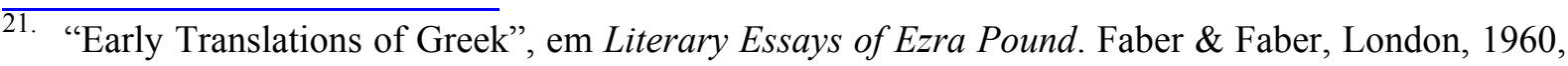
p. 268.
} 
Também as traduções livres, embora preservem, digamos, o registro do original, podem pecar ao distorcer para aquém de um objetivo estético coerente seu conteúdo na busca por um tipo vago, supostamente superior, de fidelidade. Eis como os tradutores da Jewish Publication Society justificam sua opção por uma tradução mais idiomática:

"A translation which is stilted where the original is natural, heavy where the original is graceful, or obscure where the original is perfectly intelligible, is the very opposite of faithful., 22

A que fidelidade se referem? Se em textos sagrados com fins predominantemente doutrinários ou evangelísticos traduzidos sem grandes preocupações literárias o próprio sentido que se busca privilegiar pode perder-se numa tradução que apresente o mínimo de fluência, há que se questionar o conceito de fidelidade, seja numa tradução domesticadora, seja numa estrangeirizadora.

Não existe efetivamente tipo algum de fidelidade absoluta, sobretudo na tradução literária. Do mesmo modo que, como sugere Lawrence Venuti, deve o tradutor fazer o possível para escolher o texto a ser traduzido, precisa ele ainda tentar realizar uma seleção consciente de quais elementos pretende recriar em sua tradução, tanto da forma quanto do conteúdo.

A própria discussão acerca da fidelidade parece destituída de sentido prático, já que todos, sem exceção, tomam liberdades em relação ao texto original. Todos o distorcem, sendo preocupante que a defesa de um ou outro extremo revele certa alienação em relação a outras estratégias igualmente válidas de tradução e, pior, indisfarçável maniqueísmo.

Em meio a esse debate, o presente estudo posiciona-se como tentativa de conscientização do tradutor nesse processo para seu papel não apenas de catalisador, mas agente e intermediário cultural, pois além da língua traduz-se literatura e cultura. $\mathrm{O}$ tradutor que cegamente adota uma filosofia de tradução que despreze a literariedade de um texto ou a sensibilidade moderna, irrevogavelmente inserida num momento cultural de globalização em que se assiste a um processo de disponibilização universal da informação, desconhece seu papel nessa conjuntura e é manipulável por interesses e ideologias diversos.

The Torah: the five books of Moses. Philadelphia, Jewish Publication Society, 1999. 
Como se tentou demonstrar, não é suficiente por si só a tradução literal; livre, por sua vez, carece às vezes do literal. O equilíbrio encontra-se na liberdade empregada no resgate da literariedade do texto. É com este outro paradoxo que finalizo esta seção. Somente pela estrada estreita do fazer estritamente literatura se entrará no labirinto do texto realmente poético, um entrecruzar de traduções e tradições sem conta.

\section{Littera: perseguindo névoa-nada}

Situa-se o crítico francês Henri Meschonnic entre os que, como Walter Benjamin, valorizam a forma na tradução de literatura: deve levar-se o leitor ao idioma estrangeiro e não o oposto; um texto que apare as arestas formais da língua de partida e soe como se houvesse sido escrito na de chegada seria uma anexação, "transporia a ideologia dita dominante", criando uma "ilusão do natural". 23

A própria poesia, contudo, constitui um enorme e contínuo dissimular. Até uma receita de bolo escrita num idioma exótico aparentaria sofisticação literária numa tradução estrangeirizadora simplista. A mera transposição da forma na tradução não basta na prática como princípio e tem efetivamente de apoiar-se em critérios literários nem sempre explicitados. O principal deles é a adequação possível da forma ao conteúdo, seja segundo o bom senso e experiência literária do tradutor, seja através de projeto tradutório que faça emprego ostensivo de tradições literárias locais, o que se discutirá mais tarde neste trabalho. O grande mérito de Meschonnic reside em sua visão do tradutor como criador:

“... un traducteur qui n’est que traducteur n'est pas traducteur, il est introducteur; seul un écrivain est un traducteur, et soit que traduire est tout son écrire, soit que traduire est integré à une oeuvre, il est ce "créateur" qu'une idéalisation de la création ne pouvait pas $\operatorname{voir}^{24}$."

\footnotetext{
23. MesChONNIC, Henri. Pour la poétique II: Épistémologie de l'écriture/Poétique de la traduction. Paris, Éditions Gallimard, 1973, p.308.

24. Ibid., p. 354.
} 
Liberto das amarras da tradução subserviente ao sentido, o tradutor pode e deve agora experimentar com os aspectos formais do texto. É o que fez Meschonnic ao tentar recriar do Gênesis a rude e concreta palavra hebraica, cuja concisão multivalente admirada por Auerbach traz os céus e a terra para dentro do livro. Idioma em que, paradoxalmente, Meschonnic não enxerga mistério algum:

L'histoire d'un côté, la graphie de l'autre, ne sont des mystères. Le mystère est un métalangage. ${ }^{25}$ (grifos acrescentados)

Meschonnic critica assim os que vêem a língua hebraica como concreta e visual, árida como o deserto e própria para a contemplação interior. Essa idéia não passa, para ele, de confusão entre língua e cultura; esta teria sacralizado aquela e não o oposto.

A visão de Meschonnic acerca do texto bíblico e o idioma em que foi vertido certamente não coincide com a cristã ou a do judaísmo ortodoxo; recupera, no entanto, sua literariedade, qualidade praticamente ignorada por tradutores religiosos. ${ }^{26}$ Ao traduzir a passagem da torre de Babel (Gen 11:1-9), por exemplo, Meschonnic restaura o trocadilho bavel/balal do hebraico no versículo $9:^{27}$

9.

Sur quoi elle s'appela du nom de Babel parce que là

Adonaï embabela la langue de toute la terre

É a constatação tácita de que tudo pode ser traduzido. O que não significa que Meschonnic despreze o conteúdo e se ocupe apenas da forma. O verbo bíblico, com efeito, não é apenas um sino que tine:

\footnotetext{
Ibid., p. 232.

Ao retraduzir frases de Cristo para o dialeto galileu do aramaico ocidental, o teólogo alemão Joachim Jeremias descobriu padrões formais, como trocadilhos, que variavam segundo o material e o propósito do ensino.

27. Ironicamente, é numa tradução extremamente livre, The Message, que se aplica a solução proposta por Meschonnic, e de maneira bem mais natural: That's how it came to be called Babel, because there GOD turned their language into "babble." (Gn 11)
} 
Le langage biblique est pris d'abord pour et par sa matérialité. Cette matérialité est prise comme une diction, prosodie et rythme dominant, inséparables de la signification, du rapport entre valeur et signification qui fait un texte. ${ }^{28}$

Nunca possa embora o trabalho com o significante estar ausente da linguagem poética, quer se trate de texto original ou traduzido, é a relação dialética entre forma e conteúdo que importa:

Pour fonder ce qui est texte, on a proposé le concept de forme-sens. C'est un concept. Pas deux concepts, juxtaposés, mais une unité dialectique qui n'a plus rien à voir avec les notions idéalistes de forme ou de sens. La nécessité de construire un tel concept est indiquée déjá dans tout un travail de linguistique après Saussure, à partir de la notion de système, pour rejoindre ce qu'il a disjoint : langue et parole, société et individu, posés comme des couples d'oppositions non-dialectiques. La forme-sense annule, sur le terrain de la poétique, les oppositions idéalistes telles que biographie/œuvre, thème/forme. Elle inscrit, par son trait d'union, une synthèse dialectique du sujet de l'écriture avec l'objettexte, et de l'objet-texte avec le sujet-lecteur. ${ }^{29}$

Fechando o círculo deste raciocínio, não é por acaso que tenha Meschonnic escolhido o princípio de Bereshit para ilustrar sua prática de tradução. Aqui a palavra e o ser que ela representa são um:

Et Dieu dit qu'il y ait la lumière

Et il y eut la lumière

O tradutor também é, a seu modo, um criador. Até Meschonnic, porém, precisou expor-se anteriormente a toda a herança poética francesa que culminou em Mallarmé e a ele se sucedeu. É de lá que lhe vêm os valores e padrões estéticos, ainda que pareça estar recriando unicamente com seu talento de escritor o texto original. Ou seja, o tradutor literário

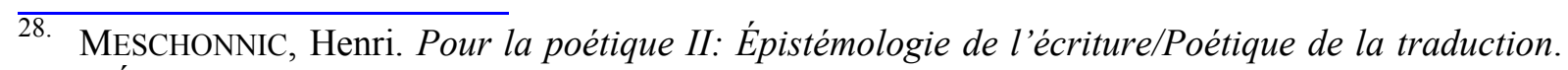
Paris, Éditions Gallimard, 1973, p. 451.

29. Ibid., p. 34. 
não apenas cria forme-sense, mas o faz, conscientemente ou não, por meio de vozes literárias da língua de chegada que permitam ao leitor local identificá-la e como tal apreciá-la.

Por que então não valorizar na tradução essa interação de tradições, processo que já lhe é natural? Diz-se que Guimarães Rosa teria certa feita traduzido para a revista Seleções do Reader's Digest um texto prosaico sobre passarinhos. Após interminável período de espera, a publicação recebeu um texto cujas qualidades superavam em muito as do original. Tivesse eu de num lema simples resumir a proposta fundamental deste trabalho, ele seria: "Nem literalidade nem liberdade, mas literariedade".

A letra, valoriza-a o tradutor e teórico francês Antoine Berman; não a tradução dita "literal", subserviente ao sentido, do tipo "palavra por palavra", mas a que trabalhe com estruturas de significantes; seriam substituídas por outras semelhantes. Depende o sucesso dessa modalidade de tradução também da habilidade do tradutor ao tentar preservar o significado enquanto trabalha com os significantes, o que Berman demonstra ao discutir a tradução de provérbios. Um equivalente pode em geral achar-se na língua-alvo que represente da sabedoria popular o mesmo princípio. Um provérbio, contudo, também é forma: tem ritmo, aliterações, vocabulário com maior ou menor concisão, etc. Cabe então ao tradutor buscar um meio-termo entre esses dois extremos: uma tradução que preserve o sentido do provérbio original e simultaneamente possua a sofisticação formal lúdica que permitiria sua cristalização na cultura popular.

Como exemplo, retoma Berman uma citação feita pelo romancista paraguaio Roa Bastos:

a cada día su pena, a cada año su daño

Propõe, em seguida, uma tradução para o provérbio acima:

à chaque jour suffit sa peine, à chaque année sa déveine

A rima do original é portanto substituída por outra: peine/déveine. Preserva-se o sentido. Em português, uma tradução possível seria:

a cada dia sua lida, a cada vida sua dor 
"Lida" tem o mesmo sentido de pena/peine; o Dictionnaire de la langue française (Larousse) traz, entre suas acepções de peine, "travail, effort pour venir à bout d'une difficulté" e também "châtiment infligé par Dieu au pécheur"-o castigo de Adão sendo o trabalho árduo necessário à sobrevivência. "Vida" e "dor" sublinham o caráter universal e fatalista da luta contra as dificuldades e são menos prosaicos que "ano"/“dano". Por fim, reforçando as aliterações com $d$, a conclusão do provérbio com o monossílabo tônico "dor" (sinônimo de "pena", "aflição" e com uma vogal fechada que contrasta com as assonâncias em $i-a$ ) tem o efeito de uma pontada.

Berman valoriza assim não o literalismo vulgar, mas a verdadeira letra como significante. Do mesmo modo, a tradução literária deve ser "l'auberge du lointain": deve acolher na língua-alvo o peregrino, o singular e o estranho, e com ele relacionar-se. Para que o tradutor de literatura explore a significância do texto que produz, é de rigor que seja portanto criador artesanal. Não é capaz aquele que cegamente traduz palavra por palavra de fabricar literatura; sua tradução acabará substituída por outra e esta por outra enquanto perdurar o interesse pelo texto original, já que as traduções foram, para acomodar-se ao mercado, descartáveis.

A tarefa não é simples. É o tradutor invisível que logra pagar as contas no final do mês. Fácil de ler e vendável é a tradução domesticadora, como admite Lawrence Venuti:

... fluency results in translations that are eminently readable and therefore consumable on the book market... ${ }^{30}$

O tradutor trabalha contra o relógio; não escolhe em princípio o que traduz e por força de contrato é obrigado a traduzir "palavra por palavra". Ainda há, porém, quem se aventure numa cruzada pela tradução verdadeiramente literária.

É o caso do ex-funcionário da USP Haroldo de Campos e seu irmão, o advogado Augusto, que quebraram barreiras consideráveis e sofreram preconceito por longo tempo até alcançarem a merecida consagração como tradutores de poesia. Nadando contra a corrente ao lado de Décio Pignatari, tornaram patente com o movimento concretista a importância da 
forma. Suas numerosas traduções de autores cuja obra evidenciasse um trabalho intenso com o significante demonstram a crença no poder da tradução de revigorar a literatura de uma nação e de uma era. Como ensina Ezra Pound:

A great age of literature is perhaps always a great age of translations; or follows it. ${ }^{31}$

Por sua prática de tradução como recriação, Pound é a influência sobre os irmãos Campos que mais nos interessa aqui. Tende a dissolver-se na obra do bardo norte-americano a linha divisória entre texto original e texto traduzido; o verdadeiro poeta tão entrelaçado se encontra com a tradição literária que o precede (o paideuma da novidade que permanece novidade) que a ele se une. O crítico chinês Ming Xie faz uma bela descrição desse aspecto em Pound:

It is in The Cantos that we see Pound's engagement with translation at its most complex. The Cantos contain numerous translations, from Homer's Odyssey, The Sacred Edict and other Chinese texts (mostly from previous European translations) to Richard of St. Victor, Ovid, Propertius and Frobenius. Interwoven with these are many of the images and motifs from Pound's previous translations: the troubadours, Cavalcanti, Old English "Seafarer", Noh plays, Cathay poems, Confucian texts. The whole sequence of Cantos starts with translation: Canto I is a rendering of the Nekyia section of Homer's Odyssey, not directly from the Greek, but from the Medieval Latin version by Andreas Divus, and then not into modern English but into the archaic idiom of the Anglo-Saxon "Seafarer". 32

Confunde-se assim com o poeta o tradutor, assumindo sua verdadeira identidade como recriador. Torna-se sua obra a arena de confronto entre tradições:

\footnotetext{
30. VENUTI, Lawrence. The translator's invisibility: a history of translation. London and New York, Routledge, 1995, p.15.

31. Citado por John Milton em O Poder da Tradução.

32. MING Xie. "Pound as translator" in: the Cambridge Companion to Ezra Pound. Edited by Ira B. Nadel. Cambridge, Cambridge University Press, 1999.
} 
The Cantos as a whole is indeed an epic of translation, with its multilingual, intertextual web of cultures and epochs, existing simultaneously in various modes of translation (as well as allusion, imitation, adaptation, quotation, and even parody). ${ }^{33}$

Esse make it new poundiano nada tem que ver com a insípida e bem comportada tradução comercial, que só ocasional e involuntariamente se mostra estrangeirizadora-por pura ignorância do vernáculo.

Como poeta, o tradutor deve recriar a linguagem da natureza:

... the Chinese still use abbreviated pictures AS pictures, that is to say, Chinese ideogram does not try to be the picture of a sound, or to be a written sign recalling a sound, but it is still the picture of a thing; of a thing in a given position or relation, or of a combination of things. It means the thing or the action or situation, or quality germane to the several things that it pictures. ${ }^{34}$

A tradução literária, em meu entender, deve atuar como imenso ideograma em dois sentidos: (a) as diferentes tradições que a compõem acabam formando o novo que o poeta busca; (b) assim como o ideograma traz em si, numa visão poética da língua chinesa, a imagem e a própria identidade daquilo que designa, forma e conteúdo devem mnemonicamente harmonizar-se num todo indecomponível.

Haroldo e Augusto absorveram a lição: suas traduções são antes de tudo literaturafruto do contato fértil de nosso idioma com o melhor da poesia universal e de um trabalho consciente e sistemático de resgate da forma, sem prejuízo do significado.

Foi por valorizar o trabalho com o significante que os irmãos Campos tornaram acessível aos leitores de língua portuguesa a fissão da linguagem na poesia mallarmaica, semente do futuro Galáxias de Haroldo, por exemplo; Joyce, Carroll, Dante, Goethe e outros foram engolidos, assimilados e consumidos num verdadeiro banquete antropofágico que forçou questões incômodas. Bruno Tolentino, por exemplo, pode ter seus argumentos, mas precisa de Augusto de Campos para afirmar sua identidade.

\footnotetext{
33. Ibid., p. 217.

34. Pound, Ezra. ABC of reading. London, Faber \& Faber, 1979, p. 21.
} 
Todo movimento carece de slogans que facilitem sua penetração na consciência das pessoas. A bandeira da "forma revolucionária" foi necessária e hoje já não pode escrever-se poesia séria no Brasil sem algum posicionamento em relação ao trabalho com o significante.

A tradução subiu ao pedestal da literatura. Pode-se constatá-lo na transcriação de Haroldo de Campos do poema sapiencial hebraico Qohélet. Como ele afirma na nota prévia:

[Minhas traduções] buscam reconfigurar uma "imagem" possível da linguagem do original, convocando, para isso, os recursos da poesia moderna, no empenho de resgatar a poeticidade do texto do fundo mortiço ou edulcorado das versões convencionais em português. Seus resultados finais devem ser avaliados em nossa língua, como trabalho de recriação poética que nela se perfaz, levando-a, quando necessário, a extremar seus limites. ${ }^{35}$

É difícil não surpreender-se com passagens como a da descrição da morte no capítulo XII, versículos 6 a 8:

6. $\quad$ Antes que se rompa $\S \quad$ a corda de prata $\S \S$

e se quebre $\S$ a copa de ouro $\S \S \S$

E se parta o cântaro $\S$ sobre a fonte $\S \S$

e a roldana quebrada $\S$ caia na cisterna

7. E o pó voltará $\S$ à terra $\S$ tal qual era $\S \S \S$

E o sopro irá de volta $\S \S$

a Elohim $\S$ que o deu

8. Névoa de nadas $\S$ disse O-que-Sabe $\S$ tudo névoa-nada

Descrição que, por sua vez, remete ao versículo 3 do primeiro capítulo:

3. Que proveito $\S$ para o homem

De todo o seu afã $\quad \S \S \quad$ fadiga de afazeres $\quad \S \quad$ sob o sol

35. CAMPOS, Haroldo de. Qohélet = O-que-sabe: Eclesiastes: poema sapiencial. Com uma colaboração especial de J. Guinsburg. São Paulo, Perspectiva, 1991. 
Sabemos que poeta é simplesmente "aquele que faz". Toda a faina humana, assim como a busca da palavra perfeita, é um contínuo correr atrás de névoa-nada, que foge e se desfaz ao toque. Haveria melhor figura do fardo do tradutor?

Essa mesma preocupação com a forma, manifesta-a Augusto de Campos. Em $O$ anticrítico encontramos a seguinte profissão de fé:

\author{
"re-criar é a meta \\ de um tipo especial \\ de tradução: \\ a tradução-arte \\ mas para chegar à \\ re-criação \\ é preciso identificar-se \\ profundamente \\ com o texto original \\ e ao mesmo tempo \\ não barateá-lo \\ enfrentar todas as suas \\ dificuldades \\ tentar reconstituir \\ a criação \\ a partir de cada palavra \\ som por som \\ tom por tom \\ é uma questão de forma \\ mas também \\ é uma questão de alma"
}

Augusto afirma que não se deve "baratear" o texto, mas "enfrentar todas as suas dificuldades". Não é ausente o sentido; antes, compõe o desafio. Mais que mera tradução centrada na forma, o trabalho do poeta-tradutor é tradução verdadeiramente literária e requer 
identificação com o original em sua poeticidade, pois nele são inextricáveis forma e conteúdo, inseridos num paideuma. Reconstituir a criação é apreender a significância do texto, sopro de vida que paira sobre ele, e inquietar-se diante do caos presente na língua-alvo até que se pronuncie o verbo - quando o criador fala, sua palavra e o que designa são um.

Comparemos sua recriação dos primeiros versos do Inferno de Dante ${ }^{36}$ com a concisa e competente tradução de John Ciardi para o inglês ${ }^{37}$ :

\section{Dal CANTO I}

Nel mezzo del cammin di nostra vita mi ritrovai per una selva oscura, ché la diritta via era smarrita.

Ah quanto a dir qual era è cosa dura, questa selva selvaggia e aspra e forte che nel pensier rinnova la paura!

\section{Do CANTO I}

No meio do caminho desta vida me vi perdido numa selva escura, solitário, sem sol e sem saída.

Ah, como armar no ar uma figura desta selva selvagem, dura, forte, que, só de eu a pensar, me desfigura?

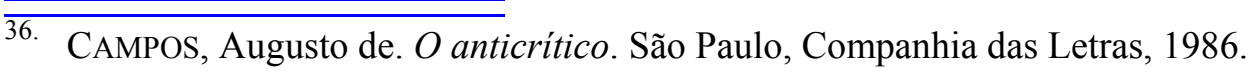




\section{From CANTO I}

Midway in our life's journey, I went astray from the straight road and woke to find myself alone in a dark wood. How shall I say

what wood that was! I never saw so drear, so rank, so arduous a wilderness!

It's [sic] very memory gives a shape to fear.

As traduções equivalem-se em termos de sentido; de fato, as ausências mais notáveis no texto de Augusto são nostra no primeiro verso, palavra perfeitamente subentendida em "desta vida" e diritta via no terceiro. Mas há uma razão estrutural para isso; em vez de apenas preservar as rimas no final dos versos, como o faz Ciardi, Augusto trabalha ainda com as internas. É de notar como, na belíssima recriação da segunda estrofe, a rima rica "figura" / "desfigura" (substantivo e verbo) torna-se exoticamente preciosa numa leitura sinestésica do original: "figura" / "dura" / "desfigura" (substantivo, adjetivo e verbo). Já as assonâncias diritta / via / smarrita na primeira estrofe são substituídas em português por rimas soantes: "solitário, sem sol, sem saída", aliterando o último vocábulo com os anteriores e formando rima soante com "vida", no primeiro verso. Veja ainda como a relação "solitário" / "sol" sublinha a sensação de solidão, já que haveria apenas um único sol a iluminar e acompanhar o poeta, não estivesse perdido na selva escura do erro e destituído ("sem sol, sem saída") da direção proporcionada pela vereda direita.

Essa diritta via, por fim, não é para o tradutor a que se mascara de fidelidade ao sentido tentando, na realidade, ocultar indisfarçável cegueira para a forma. Nem tampouco seu oposto. Nas palavras de Augusto:

é uma questão de forma mas também

é uma questão de alma

Os irmãos Campos ensinaram-nos a ler.

$\overline{37 .}$ Alighieri, Dante. Inferno. Translated, with an introduction by John Ciardi. New York, The 


\section{Imitação como recriação: a tradução ideal}

A transposição de determinada melodia ou composição para nova tonalidade constitui operação artística aceita como válida, sobretudo na música erudita, sendo particularmente comum na adaptação de peças escritas originalmente para outro instrumento ou formação. Embora as notas sejam diferentes, permanecem as mesmas, num outro tom, as relações entre elas.

É o caso da tradução como imitação da relação dialética entre forma e conteúdo no texto original. Não se trata de imitar um ou outro, mas de recriar sua síntese, sua real identidade, no texto traduzido. Só então o resultado será literatura.

A imitação não é processo estranho à tradução de literatura. Na Inglaterra do século XVII, Abraham Cowley traduzia as Odes Pindáricas de forma surpreendentemente livre, adotando da obra original apenas o que lhe aprazia, omitindo o resto e ainda acrescentando o que, em sua sensibilidade como poeta, melhor expressaria menos o sentido das palavras do poeta grego que seu "modo de falar".

Embora elogiadas por Lawrence Venuti, as traduções homofônicas de Catulo feitas por Celia e Louis Zukofsky soam pedantemente artificiais e modernosas, não obstante o mérito de seu esforço. Parecem ter ultrapassado algum limite difícil de especificar, como num transplante de coração malsucedido. Uma tradução que privilegie apenas a forma ou o conteúdo não pode ser considerada verdadeiramente literária.

A auto-imposição de limitações ou desafios formais em si é positiva e necessária. Uma exposição sucinta desse princípio, que considero fundamento da arte, encontra-se em Fantasma, de autoria de José Castello. No romance, que numa resenha pode ser descrito como a saga do autor assombrado pelo livro inexistente embora onipresente, o editor Zamenhoff aconselha o escritor acerca do melhor modo de escrever acerca de Curitiba:

Talvez o ideal fosse que eu me detivesse em algum personagem curitibano, acrescentou, alguém que não só me servisse de freio, reprimindo minha natural dispersão e moderando

Modern Library, 1996. 
minha mente, que é sempre dada aos devaneios, mas que também pudesse sintetizar a cidade ou que, ao menos, atuando como um desses mestres-de-cerimônias da televisão, cumprisse o papel de um apresentador. "Se você eleger um homem que simbolize Curitiba e dele partir, a estrada se desenrolará macia à sua frente", argumentou. Ao contrário, ele previu, se eu não me impusesse alguns limites, só encontraria um caminho cheio de obstáculos.

A liberdade gratuita e inconseqüente, com efeito, não engendra obras de valor perene como literatura. Certas obras ganham status privilegiado e tornam-se extremamente populares graças somente ao momento histórico em que surgiram, por aglutinar sentimentos e anseios pontuais que nelas obtiveram um canal de expressão. Tal é o caso de The Catcher in the Rye, do norte-americano J. D. Salinger, panfleto desprovido de maiores qualidades literárias que constitui um retrocesso em relação a Mark Twain, por exemplo, cujo Huck Finn cresce na viagem pelo Mississipi textual, subvertendo o mundo e os valores da geração que o precedeu. Para não colher exemplos na obra de um João Guimarães Rosa, cujas almas feitas de palavras não constituem apenas marcas no papel, mas visões de mundo distintas sendo criadas diante do leitor. Já o patético Caulfield não se mostra sequer capaz de verbalizar sua reação à hipocrisia que o cerca e acaba servindo, ironicamente, para perpetuar a situação dos que se espelham no protagonista.

As traduções dos Zukofsky, por outro lado, constituam embora uma inovadora e bemvinda incursão no campo da experimentação formal, talvez padeçam da ausência de inserção num projeto literário mais amplo, pois no instante em que esse trabalho com o significante se torna um fim em si, passa-se uma sensação de futilidade. Fosse a forma a finalidade única da escritura artística, refugiar-nos-íamos todos nos arranha-céus teóricos da matemática. Tratar, porém, o texto poético como fenômeno anódino indistinguível da prosa factual não faz justiça às sutilezas peculiares que reúne. Haroldo de Campos disse certa vez que é tempo de deixar de ler estrelas e passar a ler estruturas ${ }^{38}$ - lema ótimo, mas doutrina insuficiente, se levada às últimas conseqüências. Literatura é, de fato, trabalho com o significante, mas não somente isso; haja vista a legião de artistas populares que abusam de jogos de palavras gratuitos em que significante e significado deixam de formar um todo de bipartição complexa, mas constituem apenas vocábulos, sinos que tinem. 
Deve primeiro ter-se em atenção que a tradução literária é tautologicamente literatura e como tal deve posicionar-se em relação à tradição local que a precede, o que supõe a intertextualidade como instrumento crítico; a própria palavra "tradução" procede, de fato, do latim traditio e encerra idéia de entrega a alguém de algo precioso. A auto-anulação do tradutor diante da obra original evidencia não tanto uma sede do novo, mas freqüentemente subserviência e uma confissão implícita de inferioridade cultural.

Não é meu intuito, no entanto, desmerecer ou ignorar a contribuição estrangeira à literatura de um país, nem é, por outro lado, possível abafar inteiramente na tradução a voz da tradição local e muito menos a do tradutor. Ao propor que determinado autor na língua-fonte seja traduzido por meio da voz literária de outro na língua-alvo, refiro-me a índices no texto que provoquem no leitor reminiscências literárias que conduzirão ao estranhamento em decorrência da presença simultânea do outro. Assim, uma transposição para o inglês de Guimarães Rosa via James Joyce já não seria Rosa e tampouco Joyce, nem é mister, com efeito, que ocupe posição eqüidistante das tradições envolvidas. É este o ideal da tradução literária. Make it new.

Não se trata, pois, de paixão criativa ou inspiração advinda do ideal romântico de autoimolação do poeta, mas de sua habilidade em escutar o corvo a atormentá-lo com ecos de vozes da tradição que rompem os grilhões do olvido e, quais faíscas bruxuleantes do passado, por um instante esclarecem o momento literário contemporâneo. Somente em relação a essa tradição pode situar-se o novo; não, todavia, como método ou operação aritmética, mas no interagir com os arquétipos literários que insistem em assombrar a escritura de nossos dias.

38. Citado por J.J.de Moraes. 


\title{
2 \\ Práxis
}

\author{
Dreaming of apples on a wall, \\ And dreaming often, dear, \\ I dreamed that, if I counted all, \\ - How many would appear?
}

Lewis Carroll em carta a Mary Watson em 1870

\section{A tradução como desafio}

Onde se encontra a resposta ao enigma do poema acima? No tipo de material empregado na construção dos muros? Na qualidade das maçãs vitorianas? No relacionamento entre Carroll e sua amiguinha? Afinal, quantas maçãs estavam em cima do muro? Dez. A solução está no segundo verso do texto: "And dreaming of-ten, dear." A resposta encontra-se no próprio texto.

Em “A Tarefa do Tradutor", Walter Benjamin ensina que o tradutor deve tentar resgatar a forma. Mas como? Ao descascar-se uma fruta, não se pode mais cobri-la com a casca de outra. Essa impossibilidade absoluta, esse embate pelo espectro do cadáver cuja vida se esvaiu, constitui o necessário ideal inatingível do ofício tradutório.

A heurística da tradução literária é uma quimera. Embora sobrenatural, terrível com a cauda de serpente, corpo de bode, cabeça e patas dianteiras de leão, não deixa de ser mortal. Não bastam, porém, o arco e as flechas de Belerofonte, isto é, seus recursos naturais e racionais. Decisiva na vitória será sua montaria, Pégaso, que lhe permite aproximar-se do 
monstro o bastante para atingi-lo, mas a uma distância que o mantenha a salvo das chamas lançadas pela fera ensandecida.

Também o tradutor trava uma batalha com o intangível, a tarefa impossível que se impôs de traduzir literatura, e para tanto precisa abdicar do cientificismo e empregar meios também literários e, portanto, não sistematizáveis. Empregará, certamente, o arco e a flecha das palavras de seu idioma, mas, vindo do corcel alado, elas deixarão de ser armas vulgares para, das mãos do herói, assumirem uma literariedade fantástica semelhante à do ser poético desafiador.

Se a tradução literária não é também literatura, nada é. O traduzir assemelha-se ainda ao combate letal entre Perseu e Medusa, uma das três irmãs Górgonas, criaturas terríveis, como o próprio nome indica, cujos fios de cabelos se movem na forma de serpentes peçonhentas, a qual os que ousam aproximar-se petrifica com o olhar. Não pode ser morta por homem comum sem o auxílio dos deuses.

Eis que das ninfas do Norte recebe Perseu sandálias semelhantes às de Hermes, com as quais pode pairar acima da terra sobre a criatura a dormir, figura da distância, do olhar crítico necessário à tradução; de Atenas, um escudo pelo qual, e somente assim, pode fitar a forma dos seres maravilhosos, sendo esse um lembrete daquilo que nunca deve menosprezar o tradutor sério de literatura: o modo como o significante se relaciona com o significado e sua eficácia na obra em questão; por fim, o capacete da escuridão, que torna Perseu invisível e lhe permite a fuga após ter decapitado o monstro e deixado para trás as irmãs que sobreviveram. A tradução literária é a cabeça de Medusa.

Não pode o tradutor confinar-se ao que os homens consideram factível ou racional. Como herói, busca desafios, pois aspira à condição superior dos deuses de que o monstro é participante. Mas a espada de Perseu, embora presenteada por Hermes e de gume perfeito, não deixa de ser uma espada, como tal brandida pela força de um homem, assim como o arco e as flechas de Belerefonte. Não se trata de atribuir uma qualidade mística ao ato tradutório, mas de aliar a destreza e capacidade do tradutor à percepção do momento literário em que há de inserir-se sua tradução e de intuir de que maneiras uma interação frutífera com a tradição pode concretizar-se. 
Buscar sem descanso o inefável. Esse é o desafio daqueles que empunham as palavrasespada concedidas pelos deuses - o recurso à tradição literária. Mesmo que desse esforço resulte apenas (apenas!) a cabeça morta de Medusa.

\section{O problema da linguagem na tradução}

Por estar submetida a fortes interesses de mercado e inserida na indústria cultural voltada a camadas mais populares de leitores, a maioria dos tradutores goza de pouca independência em sua produção. Não há modelos ou propostas literárias que a esses profissionais ofereçam uma alternativa estética respeitável ou que simplesmente lhes confiram a dignidade devida; afinal, suas legiões de leitores exercerão influência considerável na formação de padrões literários até de escritores que aleguem não fazer concessões ao gosto popular. A cruzada dos irmãos Campos, por louvável que seja, também condena ao desprezo sistemático tais tradutores. Os estudos de tradução literária não podem, no entanto, limitar seu escopo a uma fração das traduções produzidas numa nação.

Com $O$ Clube do Livro e a tradução, John Milton contribui para preencher essa lacuna. Ao estudar as traduções do Clube do Livro publicadas no Brasil, revela-lhe a visão do livro como panacéia para todos os males, força civilizadora e saneadora da sociedade e do indivíduo. Essas nobres características se atribuem, porém, não somente a obras literárias nacionais, mas sobretudo a traduções, com todas as vicissitudes a que eram e são sujeitas. Essas traduções adaptavam os originais aos padrões de tolerância moral e estética do público pouco instruído a que se destinava. Trechos inteiros eram omitidos ou atenuados a fim de não ferir sensibilidades e manter um limite de 160 páginas por volume, decisão mercadológica então necessária.

O literalismo cômodo e automático não era, portanto, o princípio programático em que se baseavam essas traduções. Havia um propósito maior por trás dessa aparente corrupção do original por parte dos tradutores do Clube do Livro. Publicava-se um livro para que fosse lido. Há a influência clara de Monteiro Lobato, que mais tarde diria que suas obras infantis deveriam "colocar idéias no bestunto das crianças". 
John Milton também menciona algumas instruções dadas aos tradutores da Nova Cultural nos anos 70. Duas delas:

1. A tradução não deve ser literal. A história deve ser contada num bom português, com a preocupação de manter clareza, coerência e fluência.

2. Use vocabulário atual, palavras comuns, evitando repetições de qualquer natureza. Cuidado com o abuso de pronomes. Construa frases simples, na ordem direta, ou seja, sujeito-verbo-complementos. Não exagere em períodos longos ou muito curtos, ou seja, não é necessário seguir o original.

Por que são condenadas traduções como as do Clube do Livro e das Edições de Ouro? O que explicaria a rejeição dessas traduções por parte de intelectuais? Certamente não é tarefa simples resumir e adaptar uma obra literária e ainda manter algum sabor do original. Uma tradução literal seria por vezes bem mais fácil e descompromissada. Caberia então ao leitor o trabalho de decifrar o sentido oculto do texto. O tradutor permaneceria o anônimo de sempre que apenas transfere significados do código A para o código B de maneira absolutamente neutra e automática.

Exemplo da enorme resistência à manipulação profunda da linguagem pelo tradutor (em lugar da cômoda tradução "palavra por palavra") são os comentários do tradutor Ivo Barroso publicados pelo Caderno Mais do jornal Folha de São Paulo (4/11/2001):

Os grandes sucessos literários são às vezes lançados simultaneamente em várias línguas e a pressa em traduzir conduz com freqüência à contrafação. Não lemos mais o autor, cujo estilo é manipulado pelo tradutor para atender aos cânones da divulgação.

Por azar, essa prática não está circunscrita à televisão e ao livro de bolso, mas invade até mesmo as grandes editoras, quando se generaliza a tendência de "modernizar" os textos, de fazê-los "falar" a linguagem de nossa época.

Logo em seguida, revela como classifica esse trabalho:

Esse vezo de "agilizar" e "nivelar" a frase mediante a transferência das falas e situações para o tempo presente do tradutor, de colocá-las sempre ao alcance de um leitor 
hipotético e [sic] ignorante, só pode ser influência da massificante profissionalização da categoria.

Chegue embora a certa altura da resenha a admitir a possibilidade elevada da "coautoria", não deixa claro como ela ocorreria e ainda tenta achar defeitos até no trabalho de inquestionável seriedade de Henri Meschonnic. A crítica de Barroso parece fundamentar-se, como a de tantos outros, nos conceitos de inviolabilidade do original e de preservação do vernáculo.

Mexa com a linguagem e você mexerá num vespeiro. O literalismo vulgar é a patrulha moderna ao trabalho do tradutor literário. Quando não são os críticos, o próprio autor tem às vezes os brios feridos por uma recriação bem-sucedida. É o caso do poeta russo Joseph Brodsky, como narra o crítico anônimo da revista The Economist (26/1/2002):

Much the best poems in [Joseph Brodsky's "Collected Poems in English"] are those translated by important American poets-Richard Wilbur, Anthony Hecht and others. But, as Brodsky himself seems to have felt, they are so well done that they lack any trace of his Russian identity. As a result, he tried to mastermind his own translation (...). The results are almost always simply leaden. Brodsky was fluent in English, but he had no feeling for the movement of the language and accepted translations that are frankly turgid. His own attempts at writing in English are embarrassingly clumsy.

Sobeja nos poetas nativos mencionados o que aparentemente faltou a Brodsky: um diálogo com as tradições literárias locais que situariam juízos de valor como "turgid" e "clumsy" e coragem ou sensibilidade para transfigurar a linguagem.

Talvez o brasilianista Matthew Shirts tenha chegado ao cerne da questão ao identificar certo preconceito dirigido a todo escritor que faça sucesso e ganhe dinheiro. Ódio? Inveja? O fato é que escritores como Patrícia Melo, Tony Bellotto e outros vendem livros, embora na opinião do crítico Carlos Graieb eles sejam desprovidos de estilo ${ }^{39}$.

Mas é justamente esse estilo direto e, digamos, moderno o responsável pelo sucesso desses escritores. Uma opção estética consciente por linguagem e estilo narrativo adaptados à

$\overline{\overline{39 .} \text { Veja, } 6 \text { de março de 2002. O }}$ artigo motivou o comentário de Matthew Shirts em O Estado de São Paulo, 1 de abril de 2002. 
sensibilidade da cultura informatizada. E é também esse tipo de linguagem que se condena nas traduções/adaptações e imitações em geral, menos que sua omissão de passagens ou suposta "infidelidade" ao original.

A rejeição da imitação como tradução válida tanto pela intelectualidade quanto pelo mercado editorial oculta por vezes uma subserviência cega à letra morta do original, refletindo a distância que separa o tradutor literário do leitor e da tradição literária em que se insere e, acima de tudo, o medo do novo, da linguagem realmente revolucionária—será analisável com os instrumentos críticos de que dispomos hoje? Será comercial?

Há necessidade de reconciliação, nas acepções que lhes confere John Milton, da tradução aristocrática, universitária, com a desprezada "tradução de fábrica"; não, contudo, numa arbitrária padronização de normas elitistas ou popularizantes, mas numa visão comum de tradução como fenômeno eminentemente literário e interagente com a cultura, mesmo a de massa. Como tal, a tradução alteraria o paideuma segundo as características do momento histórico, destacando-se no atual, para Alvin Toffler, um abismo entre "the 'quick' and the dead".

A velocidade, com efeito, opera hoje mudanças em todas as áreas, inclusive na cultura empresarial:

... large firms are increasingly imposing standardised style and terminology rules across all their internal and external documents, including reports and web pages. Once a machine translation system has been tuned appropriately, it can produce far more accurate results if the input text is more consistent. In some cases ... firms are adopting standardised language with the specific intention of making documents easier to translate. $^{40}$

O imediatismo atual gera outras conseqüências:

The Internet changes the game for machine translation: users want speed, rather than quality, and are more likely to accept poor results. ${ }^{41}$

\footnotetext{
40. “Tongues of the Web” In: The Economist Technology Quarterly March 16 2002.

41. Ibid.
} 
A prioridade é a velocidade. Essa é a tendência contemporânea. A velocidade, por sua vez, supõe a concisão. Redações de jornais e manuais de estilo nacionais e estrangeiros seguem todos o velho conselho de Strunk \& White: "Omit needless words".

Faster não é, pois, somente o título do bestseller de James Gleick, mas a filosofia implícita deste novo milênio. Se, como defende o autor, esse movimento pela eficiência total invadirá cada vez mais o dia-a-dia do mundo civilizado (diria eu, como a cômodos da casa tomada de Cortázar), querer proibir um suposto desvirtuamento da linguagem, que na verdade seria um buscar da linguagem precisa, concisa e relevante - não muito distante do próprio dichten da poesia —é inútil e anacrônico. O tradutor, assim como o escritor, é livre; mas deve lutar para conquistar essa liberdade. Mesmo que seja um "sem estilo".

\section{Tradução: uma proposta de classificação e ação}

Todos concordamos com o tradutor Paulo Bezerra quando afirma, no prefácio de sua tradução de Crime e Castigo (Ed. 34, 2001), que "não podemos enfrentar o texto literário com a pretensão do "dois e dois são quatro"'. Aceitemos, porém, como premissa deste argumento que no texto original se possam identificar forma e conteúdo e que na poesia de qualidade eles interajam, constituindo essa interação sua própria literariedade:

\section{FORMA}

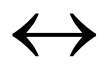

CONTEÚDO

Sabemos que o original sempre sofrerá violência e morte no ato tradutório; mas queremos que renasça e reviva em sua tradução qual fênix das cinzas - a tradução, como o pássaro, é o original e ao mesmo tempo não o é.

As categorias criadas por Dryden, por corretas e úteis que sejam, prestam-se a equívocos. Tanto a metáfrase quanto a paráfrase parecem priorizar o significado ou são empregadas como se o fizessem. A primeira tenta simultaneamente manter as qualidades formais do original; a segunda preocupa-se somente com o conteúdo; a terceira classificação, a imitação, designa as traduções que alteram, acrescentam ou omitem o significado original. 
O ideal seria que todos empregassem essas categorias como John Milton o faz em $O$ poder da tradução: a metáfrase prioriza a forma; a paráfrase, o conteúdo; e a imitação é uma recriação. Não é o que se constata, no entanto. Basta lembrar que a maioria das traduções ditas "literais" são paradoxalmente alicerçadas no significado mais preciso possível de cada palavra, comumente desprezando quaisquer outros aspectos formais. A metáfrase ideal seria, na verdade, uma tradução interlinear do Novo Testamento grego.

O fato é que nenhuma categoria é estanque. Há uma gradação entre elas, o que acaba gerando confusão em torno do caráter real de cada uma. Proponho assim uma adaptação mais clara e precisa da terminologia de Dryden:

\section{1. traduções centradas no conteúdo;}

\section{2. traduções centradas na forma;}

3. recriações ou traduções literárias propriamente ditas.

Nas traduções centradas no conteúdo, a forma é apenas coincidentemente transposta:

ORIGINAL FORMA

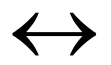

CONTEÚDO

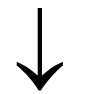

TRADUÇÃO FORMA

CONTEÚDO

Preserva-se a forma a todo o custo nas traduções centradas na forma: 
ORIGINAL FORMA
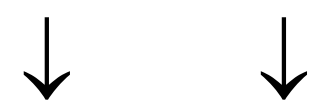

TRADUÇÃO FORMA

CONTEÚDO

Já na tradução literária propriamente dita se recria a própria interação entre forma e conteúdo:

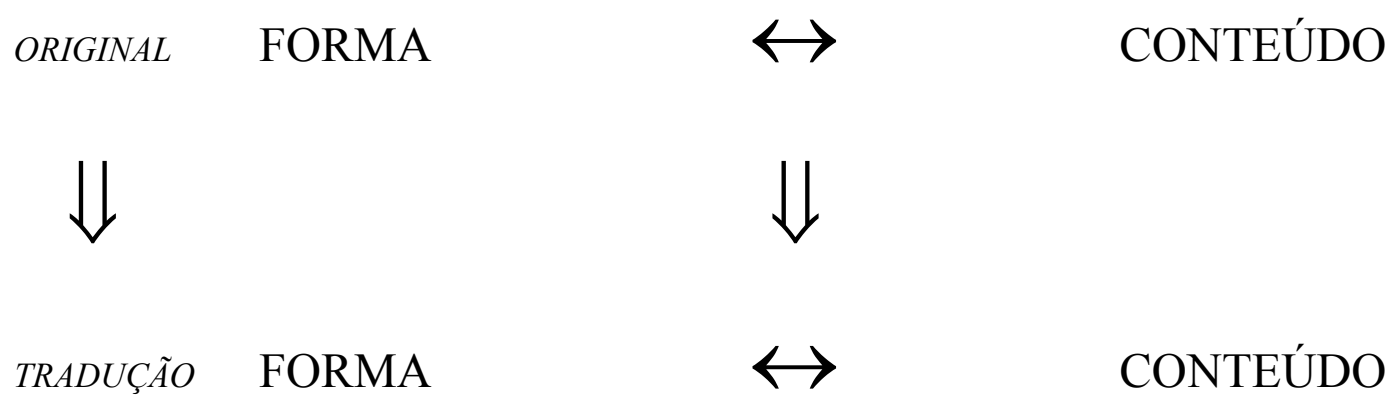

A tradução não precisa, porém, ser mero recipiente passivo da tradução literária em que o original se insere. Um tipo superior de recriação conteria elementos e até personae de tradições da língua-alvo e com eles dialogaria. Entendo que a tarefa fundamental do tradutor é justamente estabelecer um diálogo entre tradições literárias:

ORIGINAL FORMA

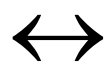

CONTEÚDO

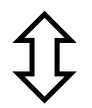

企

TRADUÇÃO FORMA

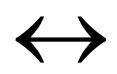

CONTEÚDO 
Trata-se de uma interação de tradições e não de uma sofisticação da tradução domesticadora, cuja política xenófoba Venuti bem descreve:

British and American publishing, in turn, has reaped the financial benefits of successfully imposing Anglo-American cultural values on a vast foreign readership, while producing cultures in the United Kingdom and the United States that are aggressively monolingual, unreceptive to the foreign, accustomed to fluent translations that invisibly inscribe foreign texts with English-language values and provide readers with the narcissistic experience of recognizing their own culture in a cultural other. ${ }^{42}$

De fato, o próprio processo de tradução de um autor por meio de outros autores fomentaria o diálogo literário (uma combinação de forças, não um enfraquecimento ou supressão do autor original) e orientaria a seleção de forma e conteúdo compatíveis e consistentes com o projeto literário do tradutor, quaisquer que fossem suas convicções estéticas. O tradutor tornar-se-ia assim sujeito e autor, conscientizando-se do papel que de certo modo sempre exercera, embora talvez sem discernimento, pois qualquer tradução revela uma preferência pontual implícita por certas formas e conteúdos, assim como por vozes literárias já presentes em sua memória que reflitam leituras passadas.

Distingo ainda três tipos de tradução literária:

1. tradução literária pessoal ou idiossincrática, em que o tradutor cria unidades forma/conteúdo segundo seu talento particular-modelo normalmente adotado pelos irmãos Campos;

2. tradução literária de inserção, de que primordialmente me ocupo neste trabalho: a tradução de literatura por intermédio de vozes literárias locais como estratégia para facilitar o confronto de tradições literárias e a efetiva inserção da obra estrangeira no paideuma local; e

3. tradução cultural, em que a tradução rompe seu confinamento às fronteiras da literatura a fim de abarcar todas as manifestações culturais possíveis.

\footnotetext{
VENUTI, Lawrence. The translator's invisibility: a history of translation. London and New York, Routledge, 1995, p.15.
} 
O trabalho do tradutor literário não se limita, de fato, à literatura, mas num nível ainda mais avançado pode valer-se de traduções intersemióticas e todas as refrações a que puder ter acesso: filmes, desenhos animados, seriados de televisão, versões infantis, canções pop, resenhas em jornais e revistas, textos de outras áreas, etc. É a tradução perfeita, inatingível, porém válida como ideal.

A tradução de Beowulf por Seamus Heaney é um ótimo exemplo de tradução cultural. Heaney usou elementos tanto de tradições orais quanto da língua e história irlandeses para recriar o épico anglo-saxão. É significativo o comentário de Julian Barnes no Times Literary Supplement: "Seamus Heaney's new translation has released the poem from the syllabus back into literature."

Quanto à tradução de inserção, não é um processo estranho ao dia-a-dia do tradutor literário. Vejamos o exemplo de Marco Lucchesi; além de esclarecer dúvidas com Umberto Eco, precisou, em sua tradução de Baudolino, "visitar algumas fontes (...): a carta do Preste João e os estudos referentes à viagem de Pero de Covilhã, de cujo imaginário depende a formação do Brasil. Para o texto medieval, visitamos $A$ demanda do santo graal, a Crestomatia, de José Nunes, as Crônicas, de Carlos Tarouca, e o Bosco deleitoso. Nas passagens do Pseudo-Dionísio, usamos a tradução da Teologia mística, de nossa autoria." 43

A visão da língua como fronteira poética a desbravar-se com elementos da língua de partida estava presente até na tradução da Odisséia realizada por Manuel de Odorico Mendes (1799-1864), concluída em 1864, um mês antes de sua morte, e publicada pela primeira vez em 1928. Considerado embora de extremo mau gosto esse texto por um estilista do porte de Antonio Candido (e anteriormente por Sílvio Romero), é inegável a ousadia de Odorico Mendes ao tentar recriar a concisão homérica na jangada da língua portuguesa. Haroldo de Campos modernamente recria a melopéia da Ilíada.

Literatura traduzida, com efeito, consiste em algo que o leitor possa classificar como literatura. Terá, portanto, necessariamente formas e conteúdos locais reconhecidos como tal em substituição a outros no momento menos eficazes. Trata-se de diálogo, confronto, interação, e não de mero refinamento da usual tradução etnocêntrica.

\footnotetext{
43. ECO, Umberto. Baudolino. Tradução de Marco Lucchesi. Rio de Janeiro, Record, 2001, p. 5.
} 
Pode empregar-se melhor esse recurso à medida que se aprende a distinguir linguagens literárias diversas nas línguas envolvidas. Como a mesma obra pode ser traduzida de inúmeros modos, a voz literária escolhida na língua-alvo terá grande peso no impacto estético que o texto traduzido exercerá. Um poeta racional e preciso como T. S. Eliot em tradução de Ivan Junqueira parece-me remeter ao Romantismo e agradará aos que relacionam poesia ao movimento: leitores médios que se lembrem com nostalgia do grupo escolar. Fosse outra a voz literária escolhida (digamos, a de João Cabral de Melo Neto), a palavra yellow nunca teria sido traduzida por adjetivos como "fúlvio" ou "dourado". Pode argumentar-se que a segunda abordagem seria uma representação mais contundente do estilo eliotiano. Ambas, porém, são exemplos entre várias possibilidades.

É necessário que o tradutor conheça o quanto possível os paideumas envolvidos. O automatismo é portanto um comodismo a ser evitado, de parte talvez o momento em que escritores consagrados exercem o papel de tradutores. É aceitável, creio, que queiram imprimir o próprio estilo a suas traduções.

Outra exceção seriam profissionais que se notabilizam por traduzir determinados autores e períodos literários. É o caso de Herbert Caro, conhecido por traduzir Thomas Mann e outros autores da literatura alemã. Sua extraordinária tradução do romance-poema Der Tod des Vergil, de Hermann Broch, coloca-o acima de muitos escritores locais no panteão literário nacional e confere-lhe, na minha opinião, autonomia para traduzir o que quiser, como quiser.

Também ocorre que tradutores de best-sellers acabem uniformizando seu estilo, refletindo tanto necessidades mercadológicas quanto a própria padronização de linguagem de tais escritores. Esse esforço no sentido de agradar ao leitor constitui alvo legítimo, pois literatura não é apenas linguagem e existe sobretudo para dar prazer.

A tradução universitária ou artesanal, termo proposto por John Milton em $O$ Clube do Livro e a Tradução, é a que permite hoje maior liberdade em relação às tradições locais, tanto na escolha do texto a ser traduzido quanto na da estratégia de tradução adotada, seja ela centrada na forma, no conteúdo ou propriamente literária. As versões "recontadas", no entanto, não se submetem a limites impostos por padrões acadêmicos e seriam assim o contexto ideal para as traduções literárias de inserção.

Uma tentativa recente de ressuscitar as traduções-adaptações seria a coleção Germinal, da Cia. das Letras. O editor Fernando Nuno e a jornalista Silvana Salerno condensam 
clássicos, tornando-os mais palatáveis ao público infanto-juvenil. Suas traduções, na realidade, aplicam o crivo de um padrão estético moderno ao texto original: "No caso de Zola, o texto, as expressões características do autor, assim como o núcleo central da história, foram mantidos", esclarece Silvana a respeito do primeiro volume, que nomeou a coleção. "A preocupação foi eliminar as longas descrições", ${ }^{44}$ justamente porque a tradução, por este prisma, não seria mero receptáculo de conteúdos a serem transferidos de um idioma para outro, mas um experimento que visa à sensibilidade contemporânea do leitor. Tanto é verdadeira essa intenção que pretende a mencionada coleção lançar versões também de obras nacionais. Temos aqui um vislumbre da tradução na acepção mais ampla da palavra.

Um movimento literário que parta de traduções de inserção é mais factível do que parece. Uma possibilidade imediata no caso brasileiro seria a recriação de clássicos em domínio público por escritores nacionais que tivessem liberdade para condensar, acrescentar e adaptar o original. Algo como "Coleção Nova Leitura", com títulos como "José Castello lê Poe", "Ignácio de Loyola Brandão lê Camus" e assim por diante. Iuri Pereira, da Editora Hedra, pretende justamente "convidar diversos nomes, como Ignácio de Loyola Brandão, para traduzirem clássicos especialmente para a nossa série", segundo reportagem do Caderno 2 do jornal O Estado de São Paulo (24/3/2001).

Num segundo momento, tradutores talentosos poderiam traduzir com estilos aproximados aos de escritores brasileiros consagrados do passado para, em seguida, almejar o vasto meio-termo da verdadeira tradução de inserção em que elementos de ambas as culturas interagem em combinações várias consistentes com projetos poéticos definidos. Um banquete literário que revigoraria nossa literatura, dando-lhe sabor menos provinciano e tornando-a mais competitiva no mercado internacional. Mesmo limitando-se a obras que não exijam o pagamento de direitos autorais, tais iniciativas teriam a seu dispor clássicos que os jovens brasileiros certamente nunca leram, além de literaturas inteiras (como as dos países escandinavos) praticamente ignoradas pelo mercado editorial de língua inglesa (e, por extensão, o nosso). Talvez o problema se resuma simplesmente na falta de profissionais de marketing realmente competentes.

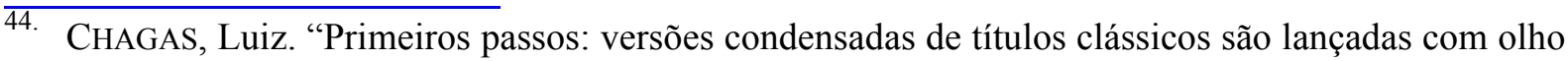
no público jovem" em Istoé, 30/1/2002.
} 
Podemos estar caminhando nessa direção. Haroldo e Augusto de Campos nos legaram traduções que privilegiavam a forma e, no entanto, tentavam preservar o conteúdo (haja vista a "lei da compensação" de Haroldo). É sintomático, porém, que qualquer tentativa de ampliar os limites impostos ao ofício tradutório seja recebida não com desconfiança, mas com desprezo e rejeição automáticos. Tal é o caso, por exemplo, da empreitada do jovem tradutor paulista Ricardo Lísias $^{45}$, que recebeu a difícil tarefa de terminar a tradução de Oliver Twist iniciada por Machado de Assis para o Jornal da Tarde, vespertino carioca.

Uma resenha não assinada na revista Veja (20/3/2002) principia por qualificar a tradução de Machado como "porcaria", não tanto por ter partido da tradução francesa, mas por ter adotado "o procedimento duvidoso de resumir ou cortar passagens inteiras da obra". É engraçado que o mesmo crítico chame a tradução que Machado fez de The Raven uma "jóia" da tradução- o que, a meu ver, trai enorme complacência (sobretudo em comparação com a tradução realizada por Fernando Pessoa) ou a típica arrogância dos que consideram a tradução uma atividade subalterna, destituída de segredos ou sofisticação.

Lísias foi encarregado de traduzir cerca de 25 capítulos da obra de Dickens no estilo machadiano. Assim como o original do escritor inglês, a tradução de Machado era publicada como folhetim. A publicação seriada exigia certa adequação à linguagem direta e concisa dos jornais-precisava-se, é claro, seduzir os leitores. Daí os cortes e omissões execrados pelo crítico.

O estilo envolve muito mais que concisão, explica ao jornal O Estado de São Paulo (24/3/2001) Iuri Pereira, um dos diretores da Editora Hedra:

O texto resultante da tradução contemporânea deveria considerar marcas de estilo presentes no texto machadiano e também marcas próprias de um trabalho do final do século $19 \ldots$

Essas diretrizes inserem-se numa visão sofisticada e, acima de tudo, coerente do ato tradutório. Nas palavras de Lísias:

Não interessa aqui, evidentemente, discutir se a literatura de Machado-ou melhor, qualquer literatura — reflete a sociedade em que se instala ou se é releitura particular da

$\overline{45 . ~ F o i ~ A l m i r o ~ P i s e t t a ~ q u e ~ m e ~ c h a m o u ~ a ~ a t e n c ̧ a ̃ o ~ p a r a ~ e s t a ~ t r a d u c ̧ a ̃ o . ~}$ 
tradição que a antecede e determina; muito embora, se precisar optar, o presente ensaio alie-se à segunda hipótese. Para o caso, vale notar que o trabalho de tradutor de Machado de Assis ultrapassa o mero papel de coadjuvante e chega até mesmo a servir, como Oliver Twist, de pista para o esclarecimento de suas afinidades não apenas genéricas, mas, mais amplamente, literárias. ${ }^{46}$

Não existe a figura do tradutor ausente. Ele trabalha com textos a partir da tradição que já assimilou. Iniciativas como a desse bravo tradutor e sua editora, que devolvam ao ofício tradutório seu caráter literário, portanto artesanal e criativo, e situem o tradutor num nível artístico superior ao de datilógrafo bilíngüe, são dignos de respeito e louvor e abrem possibilidades para experimentos mais ousados na área de tradução no Brasil.

Como esclarece Ricardo Lísias na apresentação de sua tradução, "quer-se aqui situar o tradutor não como coadjuvante, mas sim como titular de um papel criativo e, sobretudo, crítico". ${ }^{47}$

\section{Exemplos: a tradução centrada no conteúdo}

Não há, em princípio, limites para a tradução literária. Não basta, porém, afirmar que todas as traduções são válidas e assim eximir-se da tarefa crítica. Por isso, considero útil fornecer exemplos dos vários tipos de tradução mencionados.

São exemplos e não modelos ideais. Tento aplicar a lição de Pound em $A B C$ of reading: teorize pouco e observe muito. Este trabalho é o resultado de minhas observações.

Uma tradução convencional tentaria apenas transpor o conteúdo do texto original, mantendo seu registro. Eis uma tradução para o inglês, nesses moldes, do poema "As mãos de meu pai”, de Mário Quintana (as traduções seguintes, salvo indicação em contrário, são de minha autoria):

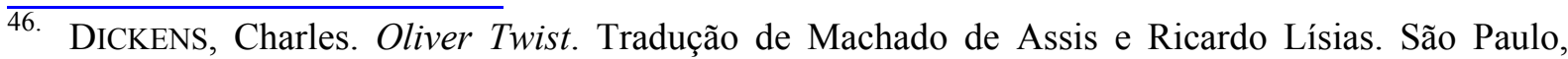
Hedra, 2002, p. 16.

47. Ibid., p. 21.
} 


\section{The Hands of my Father}

Your hands have thick veins like blue cords

On a background of earth-coloured spots

— how beautiful your hands are

for the way they handled, caressed or quivered in the nobel wrath of the righteous!

Because in your hands, my old father, there is that unique beauty called life.

At twilight, as they rest on the arms of your favourite chair,

a light seems to flicker from within them...

Does it spring from the flame you have been faithfully feeding in this merciless, desolate world

like a man who gathers some small sticks and tries to kindle them despite the wind?

Ah, how they burnt and blazed at the touch of your miracle hands!

And life still transfigures their nodes, The same life-transcending flame

Which angels shall finally call soul.

\section{As Mãos de Meu Pai}

As tuas mãos têm grossas veias como cordas azuis

Sobre um fundo de manchas já da cor da terra

— como são belas as tuas mãos

pelo quanto lidaram, acariciaram ou fremiram da nobre cólera dos justos...

Porque há nas tuas mãos, meu velho pai, essa beleza que se chama simplesmente vida.

E, ao entardecer, quando elas repousam nos braços da tua cadeira predileta, 
Uma luz parece vir de dentro delas...

Virá dessa chama que pouco a pouco, longamente, vieste alimentando na terrível solidão do mundo,

Como quem junta uns gravetos e tenta acendê-los contra o vento?

Ah! como os fizeste arder, fulgir, com o milagre das tuas mãos!

E é, ainda, a vida que transfigura as tuas mãos nodosas...

essa chama de vida - que transcende a própria vida

... e que os Anjos, um dia, chamarão de alma.

O próximo texto é outro exercício de tradução centrada no conteúdo. Não se pode, é claro, descurar por completo da forma; aqui, por exemplo, preservo as rimas e adoto como ideal estilístico a concisão possível em português.

\section{from The Unknown Eros: A Farewell}

\section{Coventry Patmore}

Não quero, mas desejo

De adeus um beijo.

Querida,

Bom que a via é límpida.

Sem pejo,

Pés contrariados,

Lágrima vertida,

Prosseguimos a ida,

Tu para o oriente, eu para o ocidente.

Não teremos

Esperança, não vemos.

Mas se, meu bem,

Tivermos visto, como num aborto,

Nosso luto-de-peito

Morto 
E vislumbrarmos a luz que emana

Do vespertino céu de porcelana,

Podemos

Na noite, pela luz (vemos),

Pela fé de pés ainda contrariados

Que cumprem seus tempos de exílio,

Ser, quem diria, conciliados;

Jornada amarga aos córregos adocicados

Temperando o eterno banquete de nosso idílio

Com as lágrimas nunca enxutas do encontro.

\section{from The Unknown Eros: A Farewell}

Coventry Patmore

With all my will, but much against my heart,

We two now part.

My Very Dear,

Our solace is, the sad road lies so clear.

It needs no art,

With faint, averted feet

And many a tear,

In our opposed paths to persevere.

Go thou to East, I West.

We will not say

There's any hope, it is so far away.

But, O, my Best,

When the one darling of our widowhead,

The nursling Grief,

Is dead,

And no dews blur our eyes

To see the peach-bloom come in evening skies,

Perchance we may,

Where now this night is day,

And even through faith of still averted feet, 
Making full circle of our banishment,

Amazed meet;

The bitter journey to the bourne so sweet

Seasoning the termless feast of our content

With tears of recognition never dry.

\section{Exemplos: a tradução centrada na forma}

A próxima tradução ${ }^{48}$ é centrada na forma:

from Sonnets from the Portuguese

Elizabeth Barrett Browning

XLIII

Como te amo? Tantos modos são.

Te amo até o ápice, amplo e fundo

Que minh'alma atinge quando só,

Sem a graça pura do Eterno Deus.

Te amo com a sede intensa e quieta,

Meio-dia ou na escuridão.

Te amo como quem busca a Verdade;

Puro e santo, do Altar tirado,

Amor que das tristezas do passado

E paixões e fé ainda vive,

Amor que se perdera na ilusão.

Sim, eu te amo, lágrimas e gozo,

Fôlego de vida! Se Deus quiser,

Hei de amar-te, mais e mais, no Céu.

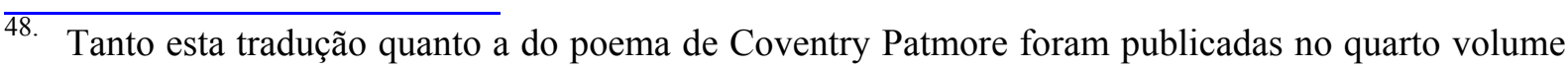
dos Cadernos de Literatura em Tradução (Humanitas). 
from Sonnets from the Portuguese

Elizabeth Barrett Browning

\section{XLIII}

How do I love thee? Let me count the ways.

I love thee to the depth and breadth and height

My soul can reach, when feeling out of sight

For the ends of Being and Ideal Grace.

I love thee to the level of every day's

Most quiet need, by sun and candlelight.

I love thee freely, as men strive for Right;

I love thee purely, as they turn from Praise;

I love thee with the passion put to use

In my old griefs, and with my childhood's faith;

I love thee with a love I seemed to lose

With my lost saints, - I love thee with the breath,

Smiles, tears, of all my life! - and, if God choose,

I shall but love thee better after death.

Menos importante que o número exato de sílabas poéticas em tais traduções é a cantabilidade do verso. A tradução é feita para receber melodia idêntica à que poderia ter o poema original. Uma adaptação faz-se ainda mais necessária devido à relativa carência de monossílabos e palavras oxítonas em português:

Te /a / mo a / té o / á / pi / ce,/ am / plo e / fun / do

Que / mi / nh'al / ma a /tin / ge / quan / do / só,/

Normalmente contaríamos somente nove sílabas na escansão do segundo verso acima (terceiro do poema). Mas como numa canção não se desperdiçam sons, sistematicamente conto a sílaba extra como a primeira do verso seguinte, formando assim mais um 
decassílabo. Este é metricamente mais próximo do original e força a uma dicção mais concisa em português. Poderia também ter escolhido quaisquer outros metros simples na nossa língua.

Eis um exemplo de tradução centrada na forma que tente preservar o ritmo:

(from Mário Quintana, Apontamentos de História Sobrenatural)

\section{RHYTHM}

The door

the housewife moves and sweeps it clean

sweeps it clean

sweeps it clean

The basin

the little maiden cleans her teeth

cleans her teeth

cleans her teeth

The brook

the washerwoman beats her clothes

beats her clothes

beats her clothes

until at last

the world goes round

and round and round

the string is off, it's set in motion like a top!

\section{RITMO}

Na porta

A varredeira varre o cisco

varre o cisco 
varre o cisco

\author{
Na pia \\ a menininha escova os dentes \\ escova os dentes \\ escova os dentes
}

No arroio

A lavadeira bate roupa

bate roupa

bate roupa

até que enfim

se desenrola

toda a corda

e o mundo gira imóvel como um pião!

\title{
Exemplos: a tradução literária pessoal ou idiossincrática
}

Ao visitar o Brasil em 1928, Rudyard Kipling (1865-1936) compôs o seguinte poema:

\section{SONG OF THE DYNAMO}

The Father of Lightning-

How Power came to São Paulo

Rudyard Kipling

How do I know what Order brings

Me into being?

I only know, if you do certain things, I must become Your Hearing and your Seeing

Also your Strength, to make great wheels go round, And save your sons from toil, while I am bound!

What do I care how you dispose 
The Bowers that move me?

I only know that I am one with those

True Powers which rend the firmament above me,

And, harrying earth, would save me at last-

But that your coward foresight holds me fast!

A tradução seguinte do poema escrito pelo conhecido estilista da língua inglesa foi realizada por Ronald de Carvalho (1893-1935). Convertido ao modernismo paulista, este poeta parnasiano e crítico literário fluminense declamou poemas durante a Semana de Arte Moderna em fevereiro de 1922, do palco do Teatro Municipal de São Paulo, além de apresentar a conferência "A pintura e a escultura moderna no Brasil”. Eis sua tradução:

\section{O CANTO do DínAMo \\ O Pai dos relâmpagos-}

\section{Como o Poder veio a São Paulo}

Tradução de Ronald de Carvalho

Como poderia saber que Providência

me deu o ser?

Sei apenas que, a um aceno vosso, devo tornar-me vosso ouvido e vossos olhos;

E vossa Força, também, para fazer girar grandes rodas

E libertar do jugo vossos filhos, enquanto

permaneço agrilhoado!

Que importa conhecerdes

os poderes que me movem?

Sei apenas que estou conjugado àqueles verdadeiros poderes, que rompem os espaços alterosos,

E, violentando a Terra, poderiam salvar-me, um dia, Se não fosse o espectro covarde que me retém para sempre encadeado.

Ofereço a seguir uma tradução alternativa do mesmo poema, tentando preservar características da tradução de Ronald que me pareçam hoje relevantes. São ambas recriações 
pessoais, repito, em que o tradutor busca o poema que lhe seja satisfatório, sem situá-lo ostensivamente num projeto estético-literário.

\title{
O CANTO Do DínAMo \\ O Pai do Relâmpago- \\ Como chegou a Força a São Paulo
}

Como conhecer que fiat

me cria?

Só sei que se queres

sou olhos e ouvidos

e força para te movimentar imensas engrenagens

e do suor pôr a salvo teus filhos, enquanto permaneço

acorrentado!

Que importa como

me moves?

Sei é que sou um com

os verdadeiros poderes que rasgam os céus nas alturas

e, assediando a terra, por fim me salvariam,

não fosse tua mira covarde a me aprisionar!

Estes versos imitam, por sua extensão e ritmo, as engrenagens de que tratam:

\author{
Só sei que se queres \\ sou olhos e ouvidos \\ e força para te movimentar imensas engrenagens
}

Ao ser escrita, a palavra revolta-se contra o autor e segue seus próprios caminhos. O tempo altera contexto cultural, leitores e o próprio valor relativo de uma tradução; não se pode quantificar o número de traduções possíveis. Numa tradução pessoal, o tradutor quer apenas agradar a si mesmo. 


\title{
Exemplos: a tradução literária de inserção
}

Gaúcho de Alegrete, Mário Quintana falava da morte, do tempo, da velhice e, é claro, da poesia, em poemas de diversas formas que, sob aparente despojamento, escondem refinada sofisticação. Vejamos como ele pode numa tradução falar mais de perto ao leitor de língua inglesa:

\author{
Guerra \\ Os aviões abatidos \\ são cruzes caindo do céu.
}

\section{WAR}

Planes shot down;

Crosses falling from the sky.

O original constitui uma única oração. Ao substituirmos, porém, o verbo de ligação pelo ponto-e-vírgula, remetemos um possível leitor inglês ou norte-americano ao Ezra Pound da fase imagista:

\section{IN A STATION OF THE METRO}

The apparition of these faces in the crowd;

Petals on a wet, black bough.

Podemos também empregar na tradução vocábulos significativos da tradição literária local:

\section{To My Dear and Loving Husband}

If ever two were one, then surely we.

If ever man were loved by wife, then thee.

If ever wife was happy in a man,

Compare with me, ye women, if you can. 
I prize thy love more than whole mines of gold,

Or all the riches that the East doth hold.

My love is such that rivers cannot quench,

Nor ought but love from thee give recompense.

Thy love is such I can no way repay;

The heavens reward thee manifold I pray.

Then while we live, in love let's so persevere

That when we live no more, we may live ever.

\section{Ao Meu Querido e Amado Esposo}

Se houve dois que um já foram, nós.

Se homem algum amado foi, sois vós.

Se alguma esposa foi feliz com alguém,

Se comparada a mim, não é ninguém.

A minas d'ouro excede o vosso amor,

A todo bem que do nascente for.

Meu amor os rios não podem cobrir,

Somente o vosso amor pode suprir.

Mas como a amor assim corresponder

Se não de Deus amor a vós descer?

Enquanto vivo, a amar-te seguirei;

No céu p'ra sempre juntos viveremos.

Observe como a sílaba extra do último verso sublinha o conceito puritano de vida eterna que transcende a presente. Nesta tradução de inserção empreguei ecos do Cântico dos Cânticos em traduções portuguesas do Antigo Testamento. O vocabulário procura a simplicidade no sublime que caracteriza o poema bíblico.

Consideremos ainda o poema "The Walrus and the Carpenter", de Lewis Carroll, famoso sobretudo pela seguinte estrofe:

'The time has come,' the Walrus said,

'To talk of many things: 


$$
\begin{gathered}
\text { Of shoes - and ships - and sealing wax- } \\
\text { Of cabbages - and kings - }
\end{gathered}
$$

And why the sea is boiling hot-

And whether pigs have wings.'

O gosto pelas relações excêntricas é presente também em nosso Mário Quintana:

\section{Da PaginaÇão}

Os livros de poemas devem ter margens largas e muitas páginas em branco e suficientes claros nas páginas impressas, para que as crianças possam enchê-los de desenhos - gatos, homens, aviões, casas, chaminés, árvores, luas, pontes, automóveis, cachorros, cavalos, bois, tranças, estrelas - que passarão também a fazer parte dos poemas...

A escolha do autor-alvo é arbitrária. Foi o poema em prosa acima que me levou a optar por Quintana para autor-alvo na tradução de "The Walrus and the Carpenter", ainda que pudesse ter escolhido qualquer outro poeta. Igualmente, outros critérios também seriam válidos.

Não é necessário que o autor-alvo equivalha ao autor que pretende traduzir-se: não tem de ocupar posição semelhante no paideuma da língua-alvo ou exibir temática e opções formais parecidas. A tradução de inserção permite tal liberdade; em vez de manietar o tradutor, abre-lhe um leque de possibilidades.

Tampouco é mister que o tradutor tente uma conformação total do original a seu alter ego literário. Uma distância calculada, de fato, presta-se melhor ao propósito de estimular o intercâmbio de heranças literárias. Basta que a tradução tenha elementos que provoquem simultaneamente familiaridade e estranhamento — a inserção.

\section{The Walrus and the Carpenter}

"The sun was shining on the sea,

Shining with all his might:

He did his very best to make

The billows smooth and bright- 
And this was odd, because it was

The middle of the night.

The moon was shining sulkily,

Because she thought the sun

Had got no business to be there

After the day was done-

'It's very rude of him,' she said,

'To come and spoil the fun!'

The sea was wet as wet could be,

The sands were dry as dry.

You could not see a cloud, because

No cloud was in the sky:

No birds were flying overhead-

There were no birds to fly.

The Walrus and the Carpenter

Were walking close at hand:

They wept like anything to see

Such quantities of sand:

'If this were only cleared away,'

They said, 'it would be grand!'

'If seven maids with seven mops

Swept it for half a year,

Do you suppose,' the Walrus said,

'That they could get it clear?'

'I doubt it,' said the Carpenter,

And shed a bitter tear.

'O Oysters, come and walk with us!'

The Walrus did beseech.

'A pleasant walk, a pleasant talk, 
Along the briny beach:

We cannot do with more than four,

To give a hand to each.'

The eldest Oyster looked at him,

But never a word he said:

The eldest Oyster winked his eye,

And shook his heavy head-

Meaning to say he did not choose

To leave the oyster-bed.

But four young Oysters hurried up,

All eager for the treat:

Their coats were brushed, their faces washed,

Their shoes were clean and neat-

And this was odd, because, you know,

They hadn't any feet.

Four other Oysters followed them,

And yet another four;

And thick and fast they came at last,

And more, and more, and more-

All hopping through the frothy waves,

And scrambling to the shore.

The Walrus and the Carpenter

Walked on a mile or so,

And then they rested on a rock

Conveniently low:

And all the little Oysters stood

And waited in a row.

'The time has come,' the Walrus said,

'To talk of many things: 
Of shoes - and ships - and sealing wax-

Of cabbages - and kings-

And why the sea is boiling hot-

And whether pigs have wings.'

'But wait a bit,' the Oysters cried,

'Before we have our chat;

For some of us are out of breath,

And all of us are fat!'

'No hurry!' said the Carpenter.

They thanked him much for that.

'A loaf of bread,' the Walrus said,

'Is what we chiefly need:

Pepper and vinegar besides

Are very good indeed-

Now, if you're ready, Oysters dear,

We can begin to feed.'

'But not on us!' the Oysters cried,

Turning a little blue.

'After such kindness, that would be

A dismal thing to do!'

'The night is fine,' the Walrus said.

'Do you admire the view?

'It was so kind of you to come!

And you are very nice!'

The Carpenter said nothing but

'Cut us another slice.

I wish you were not quite so deaf-

I've had to ask you twice!' 
'It seems a shame,' the Walrus said,

'To play them such a trick,

After we've brought them out so far,

And made them trot so quick!'

The Carpenter said nothing but

'The butter's spread too thick!'

'I weep for you,' the Walrus said:

'I deeply sympathize.'

With sobs and tears he sorted out

Those of the largest size,

Holding his pocket-handkerchief

Before his streaming eyes.

'O Oysters,' said the Carpenter,

'You've had a pleasant run!

Shall we be trotting home again?'

But answer came there none-

And this was scarcely odd, because

They'd eaten every one."

\section{A Morsa e O CARPINTEIRo}

O sol brilhava sobre o mar,

Brilhava com ardor:

Fazia tudo pra deixar

As ondas com fulgor -

Estranho, pois a hora era

De escuridão.

Que cara feia a lua fez

Porque achou que o sol

Não tinha nada que entrar

Na noite qual farol - 
"Que petulância", disse então,

"Por isso estou de mal!"

O mar molhado, ensopado,

A areia seca, pó,

O céu limpinho. Nuvens? Quê!

Não tem nenhuma só.

No céu não vejo passarinho,

Pois não tem um só.

A Morsa e o Carpinteiro vão

Andando sem alento;

Então encontram uma pedra

Boa como assento.

A pé—sem pés!-Ostrinhas vêm

Ouvir atentamente.

"Agora é tempo", a Morsa diz,

"De coisas mil falar:

Sapatos-barcos-ceras-lacre-

Reis-repolhos-mar,

Que ferve e ferve e ferve mais -

Há porcos alados pelo ar?"

"Derramo lágrimas por vós",

A Morsa se enternece

E soluçando, separando-as

Para si à beça,

Punha o lenço pra esconder-

Chorando fez a festa.

"Ó Ostras", diz o Carpinteiro,

"Que passeio bão!

Que tal voltar pra casa já?" 


$$
\begin{aligned}
& \text { Resposta veio não - } \\
& \text { E tal não era de estranhar, } \\
& \text { Nas panças em que estão. }
\end{aligned}
$$

Decidi arbitrariamente preservar o esquema métrico e de rimas do original. A versatilidade de Quintana como poeta também contribui para autorizar essa escolha.

Outro aspecto que remete a Quintana é a simplicidade aparentemente infantil do léxico e dos argumentos - simplicidade que oculta a violência e a dissimulação do real. Palavras repetem-se (shining - primeiro e segundo versos; "brilhava" na tradução) sem pudor, pois a linguagem aqui é mero simulacro.

Podem justificar-se escolhas como "pra" na tradução documentando-se o emprego de formas sincopadas e de registro informal em Quintana. Um exemplo seria a terceira estrofe do poema "Deve Haver Tanta Coisa Desabada":

$$
\begin{aligned}
& \text { Manchas de sangue inda por lá ficaram, } \\
& \text { Em cada sala em que me assassinaram... } \\
& \text { Pra que lembrar essa medonha história? }
\end{aligned}
$$

Igualmente, a liberdade com as rimas fundamenta-se em poemas como "O Poeta Começa o Dia":

Pela janela atiro meus sapatos, meu ouro, minha alma ao meio da rua.

Como Harum-al-Raschid, eu saio incógnito, feliz de desperdício...

Me espera o ônibus o horário a morte - que importa?

Eu sei me teleportar: estou agora

Em um Mercado Estelar... e olha!

Acabo de trocar

em meio aos ruídos da rua

alheio aos risos da rua -

todas as jubas do Sol

por uma trança da Lua! 
Quintana podia, contudo, dominar formas mais comportadas, como em "Dorme Ruazinha":

Dorme, ruazinha... É tudo escuro...

E os meus passos, quem é que pode ouvi-los?

Dorme o teu sono sossegado e puro,

Com teus lampiões, com teus jardins tranqüilos...

Dorme... Não há ladrões, eu te asseguro...

Nem guardas para acaso persegui-los...

Na noite alta, como sobre um muro,

As estrelinhas contam como grilos...

O vento está dormindo na calçada,

O vento enovelou-se como um cão...

Dorme, ruazinha... Não há nada...

Só os meus passos... Mas tão leves são

Que até parecem, pela madrugada,

Os da minha futura assombração...

Tomaram-se ainda outras liberdades com o original. Estrofes foram eliminadas porque não sustentariam em português o clima de absurdo do original sem cair num ridículo involuntário. O último verso da estrofe principal ressalta minha opção por uma leitura mais adulta do poema escrito por Mr. Dodgson, professor de lógica:

“Agora é tempo", a Morsa diz,

"De coisas mil falar:

Sapatos - barcos - ceras-lacre -

Reis - repolhos - mar,

Que ferve e ferve e ferve mais -

Há porcos alados pelo ar?" 
Adrede mais longo que os demais, o último verso representa o cerne da lógica ocidental tradicional, baseada na dicotomia falso/verdadeiro que angustia a tradução literária. To be or not to be? O impossível não é possível. Ou é?

\begin{abstract}
"You can just see a little peep of the passage in Looking-glass House, if you leave the door of our drawing-room wide open: and it's very like our passage as far as you can see, only you know it may be quite different on beyond. Oh, Kitty, how nice it would be if we could only get through into Looking-glass House! I'm sure it's got, oh! such beautiful things in it! Let's pretend there's a way of getting through into it, somehow, Kitty. Let's pretend the glass has got all soft like gauze, so that we can get through. Why, it's turning into a sort of mist now, I declare! It'll be easy enough to get through-"
\end{abstract}

É preciso atravessar o espelho. Ao fazê-lo, nesta passagem de Through the looking glass and what Alice found there, Alice efetivamente traduz. A casa do espelho parece idêntica à sua, mas traz elementos que levam a menina a olhar seu mundo vitoriano de outro modo.

A dimensão dessa casa evoca um novo universo por descobrir e desbravar; novo, porém familiar; familiar, embora obedecendo a leis misteriosas que à menina ingênua e curiosa cabe decifrar; semelhante na superfície, mas quite different on beyond - a tradução literária.

Não há tradução perfeita: não se podem transpor plenamente forma, conteúdo e sua interação para outro idioma. Há tradução? Mas Alice, em vez de declarar a impossibilidade do desejo, propõe-se fingir, fazer de conta que pode acontecer, e atravessa o espelho para um simulacro. Do mesmo modo, o tradutor não se ocupa em lamentar o que não pode ser feito; ou em ver, como no epigrama de Haroldo, estrelas inatingíveis, mas identifica de início estruturas como a do espelho concreto e prosaico da casa de Alice Liddle. Essas estruturas são as palavras.

Não obstante tudo mais a que possamos recorrer no estudo do texto- traduções inclusive - a bottom line é que tudo são palavras. De certa forma, criamos nosso mundo com as palavras e depois elas nos moldam. Como em estruturas fractais, vão formando padrões macroscópicos que se repetem microscopicamente de modo apenas aparentemente aleatório 
no texto poético. Dom Quixote, herói maior que Amadis de Gaula, é produto de sua biblioteca—ou seja, de textos.

Como não há montanhas no país do espelho além daquela em que se encontra, Alice vislumbra todo um tabuleiro gigantesco. Sabe que iniciará um jogo com reis, rainhas e peças menores até chegar à oitava casa. É o papel da tradução: provocar esse diálogo de tradições e mesclar-se a elas. O peão vira rainha. 


\section{3 \\ Estudo de Caso}

As mulheres belas são infiéis.

- Ditado francês

É possível talvez argumentar-se que João Guimarães Rosa corresponderia a James Joyce na literatura inglesa. Homem refinado, poliglota, médico e diplomata, Rosa conhecia a melhor literatura ocidental, além de seus amados sertões de Minas Gerais. Dante, Goethe, Homero e outros estão todos lá, como num paideuma poundiano, e falando português!

Seu modo joyceano de criar palavras novas, às vezes confundido com mero regionalismo, intrigou gerações de leitores e críticos. Rosa conhecia rudimentos de idiomas exóticos, como húngaro, e às vezes escrevia português com, por exemplo, uma sintaxe grega. $\mathrm{Na}$ sua obra, interjeições aparentemente inocentes podem ter, por exemplo, raízes conscientes em uma língua indígena.

A preocupação de Rosa com o ritmo, aliterações, etc. é microscópica, como a de Joyce. Note-se a gradação de intensidade na fala da mãe nesta passagem de "A Terceira Margem do Rio":

Sem alegria nem cuidado, nosso pai encalcou o chapéu e decidiu um adeus para a gente. Nem falou outras palavras, não pegou matula e trouxa, não fez a alguma recomendação. Nossa mãe, a gente achou que ela ia esbravejar, mas persistiu somente alva de pálida, mascou o beiço e bramou: - "Cê vai, ocê fique, você nunca volte!" (Grifos acrescentados) 
Primeiras Estórias, Tutaméia e Grande Sertão: Veredas, o grande romance brasileiro, são os três livros brasileiros a acompanhar-nos na máquina do tempo de Wells.

"Nenhum, nenhuma", uma viagem onírica pelos reinos da memória e da tradição, é um dos contos de Primeiras Estórias. Mistério nunca totalmente descoberto, constitui um labirinto grego onde se têm vislumbres do outro. Odisseu, Penélope e Telêmaco estão todos lá representados - o micro-Ulysses de Rosa.

Não é de surpreender, pois, que estratégias poéticas adotadas por Joyce em seu épico moderno possam auxiliar-nos a recriar um pouco da riqueza de Rosa para o inglês. Procurei assim identificar algumas dessas estratégias com base em amostras representativas selecionadas da maior parte dos episódios de Ulysses, sobretudo 'Sirens ${ }^{\text {49 }}$.

Seguem-se, exemplificando as possibilidades da tradução literária de inserção, excertos do conto "nenhum, nenhuma" via James Joyce. Logo de início a luz será trazida à existência na própria página, prosseguindo onipresente até o final do texto.

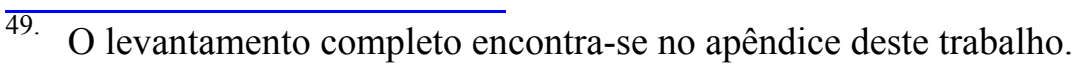




\section{none}

\section{João Guimarães Rosa}

Tnside the farmhouse, found at random among several other resought far-off places, there came to be, in our minds, irreversible great facts-reflections, flashes of lightning and sparkles-stifled by darkness. The mansion-strange, vanishing, behind mountains and ranges, ever, at the edge of the woods of some riverbank, which forbids imagining. Or perhaps it hasn't been on a farm, nor along the undiscovered path, nor that far? It is no longer possible to find out - nevermore.

(...)

Only now sluggishly there dawns the demanding glimmer of reminiscence, at the end perhaps of an extremely long journey, striking his consciousness.

(...)

Plentymuch, however, has been and is in those realms as far as my moonlight at the furthest, which I affirm and know. The house-rustic or manorial - with no visible history, just through shadows, in deaf inks: the parapeted window, the stairhead, the vacant slave bunks, the restless cattle? If I manage to recall it, I'll recover my calm; if only I could religion myself and guess the true and real one, the has-gone. Is childhood for real? 
The Young Lady and the Young Man exchanged a flamemoist gaze when they were alone; a similar gleam beamed from them, a lookalikeness. They looked at each other like sparrows on the spur of their singing with trees on tiptoe and clouds abashed-like embers she fanned into coals of fire, the vehement one. They closegazed, but drouthcalmly, not knowing, not ashamed. (...) Now the Boy wished they would never cease to look at one another that way. Unpierceable bottomless eyes, like life.

(...)

The Young Lady was the fairest among beings, endlesslessless beauty. Could be the princess in the castle, up in the tower. Who knows, black eagles round the tall turret?

(...)

They let him know what was inside the room. They let him peek. It was an ages old elderly lady of old of ages, an inconceivably ancient woman.

(...)

They assured him, the old lady was not Death, nor was she dead. Rather, she was life! There the heart alone within contained awaiting beating breathing life the spirit Shh.

(...)

The Boy beamed inquired, "She sleepingbeautied?" The Young Lady kissed him. Life was the wind trying to put out a 
lamp. The walking shadows of a motionless me.

(...)

Revanished them remembrances, the representation of all is all out of order-really a bridge, which, all of a sudden, collapses, looks like. We fight with memory. 


\section{nenhum, nenhuma ${ }^{50}$}

Dentro da casa-de-fazenda, achada, ao acaso de outras várias e recomeçadas distâncias, passaram-se e passam-se, na retentiva da gente, irreversos grandes fatos - reflexos, relâmpagos, lampejos—pesados em obscuridade. A mansão, estranha, fugindo, atrás de serras e serras, sempre, e à beira da mata de algum rio, que proíbe o imaginar. Ou talvez não tenha sido numa fazenda, nem no indescoberto rumo, nem tão longe? Não é possível saberse, nunca mais.

(...)

Só agora é que assoma, muito lento, o difícil clarão reminiscente, ao termo talvez de longuíssima viagem, vindo ferir-lhe a consciência.

(...)

Ultramuito, porém, houve o que há, por aquela parte, até aonde o luar do meu mais-longe, o que certifico e sei. A casa—rústica ou solarenga—sem história visível, só por sombras, tintas surdas: a janela parapeitada, o patamar da escadaria, as vazias tarimbas dos escravos, o tumulto do gado? Se eu conseguir recordar, ganharei calma, se conseguisse religar-me: adivinhar o verdadeiro e real, já havido. Infância é coisa, coisa?

A Moça e o Moço, quando entre si, passavam-se um embebido olhar, diferente do dos outros; e radiava em ambos um modo igual, parecido. Eles olhavam um para o outro como os passarinhos ouvidos de repente a cantar, as árvores pé-ante-pé, as nuvens desconcertadas: como do assoprado das cinzas a esplendição das brasas. Eles se olhavam para não-distância, estiadamente, sem saberes, sem caso. (...) Mas o Menino queria que os dois nunca deixassem de assim se olhar. Nenhuns olhos têm fundo; a vida, também, não.

\footnotetext{
$\overline{50 .}$ Nestes excertos, o uso do negrito foi ignorado, já que somente funcionaria no contexto integral do conto. (Excertos de RosA, João Guimarães. Primeiras Estórias. Rio, Ed. José Olympio, 1981.)
} 
$(\ldots)$

A Moça, porém, era a mais formosa criatura que jamais foi vista, e não há fim de sua beleza. Ela poderia ser a princesa no castelo, na torre. Em redor da altura da torre do castelo, não deviam de revoar as negras águias? (...)

...deixaram-no saber o que dentro daquele dito quarto se guardava. Deixaram-no ver. E, o que havia ali, era uma mulher. Era uma velha, uma velhinha—de história, de estória—velhíssima, a inacreditável. (...)

Tranqüilizavam-no, diziam: que a velhinha não era a Morte, não. Nem estava morta. Antes, era a vida. Ali, num só ser, a vida vibrava em silêncio, dentro de si, intrínseca, só o coração, o espírito da vida, que esperava. (...)

O Menino sorriu. Perguntou:-“Ela beladormeceu?" A Moça beijou-o. A vida era o vento querendo apagar uma lamparina. $\mathrm{O}$ caminhar das sombras de uma pessoa imóvel.

(...)

Reperdida a remembrança, a representação de tudo se desordena: é uma ponte, ponte,-mas que, a certa hora, se acabou, parece'que. Luta-se com a memória. 
Este conto foi escolhido também por permitir a discussão do ato tradutório como manipulação engajada de tradições literárias. Segue-se um comentário da tradução, passo a passo, no contexto:

\section{none}

\section{João Guimarães Rosa}

Inside the

Farmhouse, Found at randOM | aMOng several other resought Far-oFF places,

- Temos aqui simetria especular, um jogo de espelhos que refletem a luz criada no princípio da narrativa, o qual se faz presente até a última palavra.

there came to be in our minds irreversible great

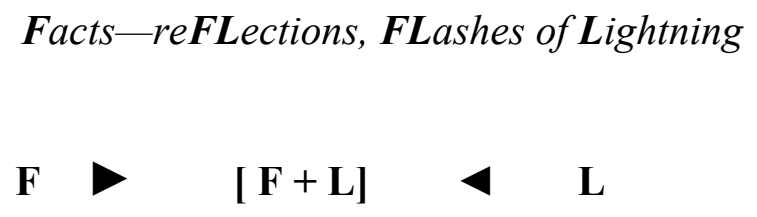

- Mas que luz é essa? É a luz $(L)$ arquetípica da memória do garoto, que representa as tradições literárias ocidentais, trazendo fatos $(F)$ que se confundem $(F L)$ e se modificam uns aos outros como espelhos que se enfrentam (...reflections, flashes...)

and

SpARKleS - StiFLed by dARKneSS. 
- A palavra stifled reflete a luz anterior (stiFLed) e ao mesmo tempo é "abafada" pelos extremos de nova simetria especular (sparkles/darkness), por sua vez citação da oposição luz/trevas do Bereshit: sparkles é a luz intermitente refletida nas águas primevas. Elementos de tradições literárias da língua de chegada (no caso, da Bíblia hebraica na King James Version) seduzem o leitor e fornecem-lhe onde pisar de início, para então deslocar e abalar seus fundamentos estéticos com o novo olhar, estranhamente mesclado ao que antes pensara ser familiar.

The mansion-strange, vanishing, behind mountains and ranges, ever, at the edge of the woods of some riverbank, which forbids imagining. Or perhaps it hasn't been on a farm, nor along the undiscovered path, nor that far? It is no longer possible to find out -

nevermore.

- Ecos de "The Raven":

"Prophet!" said I, "thing of evil! — prophet still, if bird or devil!

By that Heaven that bends above us - by that God we both adore-

Tell this soul with sorrow laden if, within the distant Aidenn,

It shall clasp a sainted maiden whom the angels name Lenore-

Clasp a rare and radiant maiden whom the angels name Lenore."

Quoth the Raven "Nevermore."

A citação de Allan Poe pretende sublinhar o mistério da narrativa e o caráter místico do esforço do menino, um Telêmaco-Homero sendo conduzido à língua inglesa; a referência ao autor de The Fall of the House of Usher é também um objective correlative que prepara esse leitor para algo semelhante à Queda da felicidade edênica, terceiro pilar do texto.

\section{(...)}

Only now sluggishly there dawns the demanding glimmer of reminiscence, at the end perhaps of 
an extremely long journey,

- Referência óbvia à Odisséia .

striking his consciousness.

(...)

Plentymuch,

- Deve ter-se em mente que além de elementos de tradições locais conhecidas (aqui, Poe, a King James Version, etc.), o tradutor insere no texto traduzido uma dicção poética local, neste caso a de James Joyce ao escrever Ulysses - o autor-alvo. Quem se dispuser a examinar com algum cuidado o apêndice no final deste estudo constatará que os neologismos não foram criados a esmo, nem foi gratuito o trabalho com o significante ao longo da tradução.

however, has been and is in

those realms

as FAR as my moonlight at the FURthest, which I afFIRm

and know.

- A delimitação do olvido, que prepara a busca do fiat lux.

The house - rustic or manorial — with no visible history, just through shadows, in deaf inks: the parapeted window, the stairhead, the vacant slave bunks, the restless cattle? If I manage to recall it, I'll recover my calm;

if only I could religion myself 
- Aqui empregado como verbo, esse substantivo, como se sabe, vem do latim 'religare' e destaca as conotações místicas do original; compensa a nominalização "meu mais-longe" do conto de Rosa.

and guess the true and real one, the has-gone. Is childhood for real?

The Young Lady and the Young Man exchanged

$$
\text { a flamemoist gaze }
$$

- Com o olhar, volta a irradiar-se a luz pelo texto. Citação velada da King James Version:

The light of the body is the eye: if therefore thine eye be single, thy whole body shall be full of light.

Matthew 6:22

when they were alone;

$$
\text { a siMilar glEAM bEAMed froM the } \boldsymbol{M} \text {, }
$$

- As aliterações e a assonância enfatizam a semelhança de que trata a frase. Som e sentido são um-característica que distingue o texto poético de jogos de palavras vãos.

Lembra versos de Gerard Manley Hopkins:

And all is seared with trade; bleared, smeared with toil

(de God's Grandeur)

a lookalikeness. They looked at each other like

SPARrows on the SPUR of their singing 
- Imita o canto dos passarinhos, novamente lembrando a musicalidade mística do poeta jesuíta:

Because the Holy Ghost over the bent

World broods with warm breast and with ah! bright wings.

(de God's Grandeur)

with trees on tiptoe and clouds abashed-like embers

\section{she fanned}

- Lida ao contrário, a frase soa como a palavra hebraica nefesh, "espírito", sopro de vida concedido a Adão, episódio a que Rosa parece referir-se no original:

“... como do assoprado das cinzas a esplendição das brasas.”

into coals of fire,

the vehement one.

- Inserção da frase do Cântico dos Cânticos que acentua a intensidade do amor dos protagonistas:

Set me as a seal upon thine heart, as a seal upon thine arm: for love is strong as death; jealousy is cruel as the grave: the coals thereof are coals of fire, which hath a most vehement flame.

Song of Songs 8:6

Não é necessário que o leitor a que se destina a tradução identifique as citações. Basta que inconscientemente lhe soem familiares e assim comecem a situar o texto numa tradição literária aparentemente conhecida. $\mathrm{O}$ que não significa que qualquer citação seja apropriada. Baudelaire, por exemplo, mesmo presente no original, não seria provavelmente reconhecível 
por adultos norte-americanos de educação mediana, o leitor que nesta tradução se teve em mente.

\section{They closegazed,}

- À̀ Humpty Dumpty confiro a essa portmanteau word a seguinte acepção:

to gaze at someone so intently that one yearns to become a single being with that person (here used intransitively)...

As palavras, assim como as pessoas, mudam segundo a companhia. Se o tradutor for hábil o bastante ao manipular o contexto, suas palavras significarão o que quiser. Rosa foi mestre nisso.

but

drouthcalmly,

- Ao traduzir "estiadamente", criei joyceanamente um neologismo:

'drouth': forma poética de 'drought' encontrada em Ulysses

$+$

'calm': do grego kauma 'calor (do dia)'!

Embora empreguemos elementos de outras fontes, a dicção poética deve ser próxima à de Joyce, o autor-alvo.

not knowing, not ashamed.

- A queda é prefigurada: 
And they were both naked, the man and his wife, and were not ashamed.

(...) Now the Boy wished they would never cease to look at one another that way.

Unpierceable bottomless $\boldsymbol{E} \boldsymbol{Y E}$, lIIke lIfe.

- As assonâncias são os ecos do poço sem fundo do olhar dos amantes!

(...)

The Young Lady was

the fairest among beings,

- Nova citação do Cântico dos Cânticos na King James Version:

...O thou fairest among women...

Song of Songs 1:6

endlesslessless beauty.

- Homenagem à famosa passagem de 'Sirens'.

Could be the princess in the castle, up in the tower. Who knows, black eagles round the tall turret?

- Elipses e fragmentos são muito freqüentes em Ulysses (V. Apêndice).

(...)

They let him know what was inside the room. They let him peek. It was 
an ages old elderly lady of old of ages, an inconceivably ancient woman.

\section{3 \\ (-derly | lady)}

2

(old)

1

(ages)
2

(old)

1

(ages)

- A extensão da frase é a longa vida da velhinha; a simetria especular de palavras e sons, o retorno à inocência fetal que a caracteriza - ela era a vida! Posto que frágil (tem inicial minúscula), enfrenta a Morte:

(...)

They assured him, the old lady was not Death, nor was she dead. Rather, she was life!

- Escute o coração de Penélope a bater no texto:

There the heart alone within contained awaiting beating breathing life the spirit Shh.

(...)

The Boy Beamed inquired, "She sleePingBeautied?"

The Young Lady kissed him. Life was the wind trying to put out a lamp. The walking shadows of a motionless me.

(...) 
Revanished thEM reMEMbrances,

the representation of

ALL is

ALL out of order-re-

ALLy a bridge, which,

ALL of a sudden, co-

LLApses,looks like. We fight with memory.

E o tradutor, com as tradições. Houve ainda um propósito alegórico por trás das citações, mesmo as veladas: a preparação para a queda de tudo (the Fall). Tivemos a queda da inocência no Paraíso, figura da perda da alegada pureza do chamado texto original, seguida da queda de Humpty Dumpty desse orgulho auto-suficiente - o original cai e se quebra; cai como a casa de Usher, que é também a de Rosa, “casa-de-fazenda, achada, ao acaso de outras várias e recomeçadas distâncias", "mansão, estranha, fugindo, atrás de serras e serras, sempre”, texto angustiado pela busca do passado tantálico a crocitar: "Nevermore!"

Raven, more! Esta é a razão das inversões e espelhos distribuídos pelo texto-ele mesmo obliquamente refletindo, do seu jeito, o que fora o texto original, com ele se fundindo e se dissolvendo em "nenhum, nenhuma", névoa-nada, no próprio som da palavra-espelho none. 


\section{Conclusão Jeito Brasileiro de Traduzir}

As traduções em geral são quase automáticas. Dois tipos prevalecem:

1. A tradução centrada no conteúdo que preserva os elementos formais que não atrapalhem a transferência de significado para a língua-alvo.

2. A centrada na forma, mas com o desafio permanente de conservar o quanto possível o sentido.

A primeira categoria, todos sabem, constitui o modelo quase oficial de tradução, sobretudo de prosa. A segunda, complexa e refinada, destina-se a uma elite cultural e confunde-se no Brasil com a tradução universitária. Abrange principalmente a poesia.

Uma possível terceira via da tradução seria um amalgamento de tradições literárias em que o elemento nacional, autóctone, dialogasse com o estrangeiro. Não se trata de anular uma das partes, mas de formar algo novo, mestiço, melhor, que agregue num todo homogêneo as qualidades de ambas. Essa miscigenação de tradições literárias, que reflete a formação de nosso povo, é que constitui o jeito brasileiro de traduzir.

Vejamos como exemplo uma tradução do texto seguinte, um excerto de Alice's Adventures Underground, uma versão anterior de Alice's Adventures in Wonderland, de Lewis Carroll ${ }^{51}$.

\footnotetext{
51. In: Milton, John, ed. Cadernos de Literatura em Tradução 3: Os Poemas Gregos de Antonio Medina. São Paulo, Humanitas, FFLCH/USP, 1999, pp. 49-54.
} 
'She saw an ancient city, and a quiet river winding near it along the plain, and up the stream went slowly gliding a boat with a merry party of children aboard. She could hear their voices and laughter like music over the water, and among them was another little Alice, who sat listening with her bright eyes to a tale that was being told — and lo, it was the dream of her own little sister.'

O texto não apresenta problemas aparentes. Linguagem simples e clara. Uma tradução nos moldes que proponho, porém, buscará uma voz literária nacional para transpô-lo.

Os critérios podem variar. Neste caso, escolhi arbitrariamente o Guimarães Rosa do conto "nenhum, nenhuma" (Primeiras Estórias), cuja atmosfera onírica lembra em muito o sonho da irmã de Alice. São as memórias turvas de um garoto em busca de seu passado.

O tradutor deve ampliar seu vocabulário lingüístico e também literário. Um levantamento do que nos chama a atenção em obras significativas do autor-alvo sempre será útil. O ensaio introdutório de Paulo Rónai no mesmo livro, "Os vastos espaços", é bom ponto de partida e modelo de análise estilística para possíveis traduções. Guiei-me aqui apenas por minhas próprias recordações de leitura ao tentar empregar a voz de Rosa.

Essa voz de Rosa seria um objective correlative, para empregar a obscura expressão eliotiana. Deve provocar reminiscências no leitor que ajudem a construir no texto a terra de sonhos de Carroll na língua portuguesa. O resultado já não é totalmente Rosa ou Carroll, mas, creio, um mestiço forte e de vida própria. É o caminho das pedras.

E viu a irmã de Alice uma cidade do passado, um rio plácido correndo próximo pela planície e, lentamente contra a corrente, gozo infantil num barco. Suas vozes e risos eram como música das águas; ali Alice, outra, ouvindo com os olhinhos úmidos o conto contado - e eis que era o sonho de sua irmãzinha.

Há na tradução um jogo de sons, quais sejam bilabiais, alveolares, velares e diversos fonemas nasais. Vejamos: 
E viu a irmã de Alice uma cidade do passado, um rio plácido correndo próximo pela planície e, lentamente contra a corrente, gozo infantil num barco. Suas vozes e risos eram como música das águas; ali Alice, outra, ouvindo com os olhinhos úmidos o conto contado - e eis que era o sonho de sua irmãzinha.

Esses sons nasais são o próprio rio correndo pelo texto; em suas ondas vemos o reflexo das águas:

...passado, um rio plácido correndo próximo pela planície e, lentamente...

Repare como as aliterações seguintes sugerem a Alice Liddell da memória, a que não cresceu e permanece para sempre no passeio de barco de 4 de julho de 1862, aquela dos olhos meigos e puros, que se regozijam com uma estória; enfim, a Alice ficcional do poema que precede Wonderland, a cúmplice do contador, num instante em que o tempo pára, seja para Charles Dodgson, seja para o leitor - o momento mágico:

....ali Alice, outra, ouvindo com os olhinhos úmidos o conto contado... 


\section{Apêndice Estudo do Autor-Alvo}

Este é um pequeno estudo estilístico realizado para a elaboração da tradução de Rosa via Joyce constante do terceiro capítulo deste trabalho. A investigação limitou-se a quatro categorias gerais $^{52}$ :

1. Aliteração: uso repetido da mesma consoante em duas ou mais palavras próximas.

2. Assonância: uso repetido da mesma vogal em duas ou mais palavras próximas.

3. Rima completa: quando aliteração e assonância coexistem em duas ou mais palavras próximas.

4. Rima visual: ocorre entre palavras cujas partes ortograficamente semelhantes não constituem na pronúncia assonância ou aliteração. Ou seja, não rimam.

5. Neologismo: na dicção poética, uma inovação vocabular.

Os neologismos prováveis aparecem sublinhados; as demais categorias, em negrito. Os episódios de Ulysses são acompanhados de algarismos romanos e os números de páginas referem-se à edição Rose (Picador, 1998).

\footnotetext{
52. A terminologia acima é livremente adaptada de The Poetry Handbook (Oxford, 1997), excelente manual de John Lennard.
} 
Este levantamento não é exaustivo, evidentemente. Outros aspectos, como a fanopéia, são significativos na obra. Em verdade, todos os sentidos:

Mr Leopold Bloom ate with relish the inner organs of beasts and fowls. He liked thick giblet soup, nutty gizzards, a stuffed roast heart, liver slices fried wih crustcumbs, fried hen-cod's roe. Most of all he liked grilled mutton kidneys which gave to his palate a fine tang of faintly scented urine. (IV - 53)

A elipse desempenha papel central na dicção joyceana:

Ham and eggs, no. No good eggs with this drouth. Want pure fresh water. Thursday: not a good day either for a mutton kidney at buckley's. Fried with butter, a shake of pepper. Better a pork kidney at Dlugacz's. While the kettle is boiling. (IV - 54)

A omissão de parte de uma palavra constitui outra estratégia interessante:

He saved the situa. Tight trou. Brilliant ide. (XI - 257)

It is $\underline{\text { utterl imposs. }}$ (XI - 266)

Ask her no answ. $(X I-266)$

A preocupação de Joyce com o ritmo não pode ser negligenciada. Note-se o impressionante compasso de quatro tempos na passagem seguinte.

Tip. An unseeing stripling stood in the door, He saw not bronze. He saw not gold. Nor Ben nor Bob nor Tom nor Si nor George nor tanks nor Richie nor Pat. Hee hee hee hee. He did not see. (XI - 277)

Por fim, como é de conhecimento geral, grandes seções de 'Penelope' carecem de qualquer sinal de pontuação - outra estratégia disponível para nossa tradução.

Eis o levantamento: 
With slit ribbons of his shirt whipping the air he hops and hobbles round the table, with trousers down at heels, chased by Ades of Magdalen with the tailor's shears. (I - 9)

Wave-white wedded words shimmering on the dim tide. (I - 11)

A cloud began to cover the sun slowly, wholly, shadowing the bay in deeper green. (I - 11)

.... and on a heath beneath winking stars a fox, red reek of rapine in his fur... (II - 29)

...Averroës and Moses Maimonides, dark men in mien and movement, flashing in their mocking mirrors the obscure soul of the world... (II - 29)

...their heads thickplotting under maladroit silk hats. (II - 34)

$[\mathrm{v}(\operatorname{adv}(\operatorname{adj})+\mathrm{v}-i n g)]$

Crush, crack, crick, crick. (III - 37)

Belly without blemish, bulging big, a buckler of taut vellum ... (III - 38)

Warring his life on the contransmagnificandjewbangtantiality. (III - 38)

.... brightwindbridled... (III - 38)

...his fists bigdrumming on his padded knees. (III - 39)

$[\mathrm{v}(\operatorname{adv}(\operatorname{adj})+\mathrm{v})]$

Shoot him to bloody bits with a bang shotgun, bits man spattered walls all brass buttons. (III - 42)

Obs.: /p/ em 'spattered' é o equivalente surdo de /b/; / m/ em 'man' é, como /b/, uma bilabial sonora.

...roaring wayawayawayawayaway. (III - 47)

She blinked up out of her avid shameclosing eyes... (IV - 53)

$[\operatorname{adj}(\mathrm{n}+\mathrm{v}$-ing $)]$ 
...poured warmbubbled milk... (IV - 54)

$[\operatorname{adj}(\operatorname{adj}+\mathrm{v}-e d)]$

Ahbeesee defeegee kelomen opeecue rustyouvee doubleyou. (IV - 56)

[partes do alfabeto]

Come home to $\underline{m a}, \underline{d a} .(\mathrm{V}-68)$

[imitação da fala]

Sweeeet song. (V - 72)

[imitação da fala]

Nose whiteflattened against the pane. (VI - 84)

$[\operatorname{adj}(\operatorname{adj}+\mathrm{v}-e d)]$

Kraahraark! Hellohellohello amawfullyglad kraark awfullygladaseeagain hellohello amawf krpthsth.

(VI - 109)

[imitação da fala]

A sugarsticky girl... (VIII - 144)

$[\operatorname{adj}(\mathrm{n}+\operatorname{adj})]$

...Mrs Breen's womaneyes said melancholily. (VIII - 150)

$[\mathrm{n}(\mathrm{n}+\mathrm{n})][\operatorname{adj}-l y]$

Sss. Dth,dth,dth! (VIII - 153)

[imitação da fala]

Junejulyaugseptember eighth. (VIII - 160)

[meses]

...no teeth to chewchewchew it. (VIII - 161)

[v(v-três vezes $)]$ 
O, the big doggybowwowsywowsy! (VIII - 166)

Davy Byrne smiledyawnednodded all in one:

Iiiiiiichaaaaaaach! (VIII - 169)

[v(v-ed $+\mathrm{v}-e d+\mathrm{v}-e d)]$ [imitação da fala]

Peter Piper pecked a peck of pick of peck of pickled pepper. (IX - 183)

Yogibogeybox in Dawson Chambers. (IX - 183)

$[\mathrm{n}(\mathrm{n}+\mathrm{n}+\mathrm{n})]$

... mahamahatma. (IX - 183)

...ringroundabout him. (IX - 183)

$[\operatorname{prep}(\mathrm{v}+\mathrm{adv}+\operatorname{prep})]$

... He-souls, she-souls, shoals of souls. (IX - 183)

...said beautifulinsadness Best...(IX - 195)

$[\operatorname{adj}(\operatorname{adj}+\operatorname{prep}+n)]$

He walked by the treeshade of sunnywinking leaves...(X - 209)

$[\mathrm{n}(\mathrm{n}+\mathrm{n})][\operatorname{adj}(\operatorname{adj}+\mathrm{v}-\mathrm{ing})]$

...of her mantilla inkshining in the sun. $(\mathrm{X}-209)$

$[\mathrm{v}(\mathrm{n}+\mathrm{v}-\mathrm{ing})]$

...she twisted twined a hair. (XI - 246)

$[\mathrm{v}(\mathrm{v}+\mathrm{v})]$

Obs.: Ignorou-se aqui a abertura de 'Sirens' e os excertos das canções, visto que nosso interesse fundamental reside na prosa não fragmentada. 
Bloowho... (XI - 246)

$[\mathrm{n}(\mathrm{n}+$ pron $)]$

- Imperthnthn thnthnthn... (XI - 247)

[imitação de 'impertinent insolence' dito em tom de deboche]

...heard steelhoofs ringhoof ringsteel. (XI - 247)

$[\mathrm{n}(\mathrm{n}+\mathrm{n})][\mathrm{v}(\mathrm{v}(\mathrm{v}+\mathrm{n})+\mathrm{v}(\mathrm{v}+\mathrm{n}))]$

Bloowhose dark eye read Aaron Figatner's name. (XI - 248)

[n-genitive $(\mathrm{n}+$ pron $)]$

In a giggling peal young goldbronze voices blended...(XI - 248)

Obs.: Tanto as vozes das personagens quanto seus nomes se misturam.

...to let freefly their laughter... (XI - 248)

$[\mathrm{v}(\operatorname{adv}(\operatorname{adj})+\mathrm{v})]$

...drank a sip and gigglegiggled. (XI - 248)

$[\mathrm{v}(\mathrm{v}$-twice $)]$

... bronzegold, goldbronze, shrilldeep, to laughter after laughter. (XI - 249)

$\left[\mathrm{n}\left(\mathrm{n}_{1}+\mathrm{n}_{2}\right)\right]\left[\mathrm{n}\left(\mathrm{n}_{2}+\mathrm{n}_{1}\right)\right][\operatorname{adj}(\operatorname{adj}+\operatorname{adj})]$

None not said nothing. Yes. (XI - 250)

Obs.: Efeitos sonoros destacam contraste com 'yes'.

Girlgold she read and did not glance. (XI - 250)

$[\mathrm{n}(\mathrm{n}+\mathrm{n})]$

Winsomely she on Bloohimwhom smiled. (XI - 252)

[n-objective $(\mathrm{n}+$ pron + pron $)]$

...to sing the strain of dewy morn, of youth, of love's leavetaking, life's, love's, morn. (XI - 252) 
Between the car and window, warily walking, went Bloom ... (XI - 253)

...walked towards Richie Goulding's legal bag, lifted aloft, saluting. (XI - 253)

Shebronze... (XI-253)

$[\mathrm{n}($ pron $+\mathrm{n})]$

Neatly she poured slow syrupy sloe. (XI - 254)

[Boylan's coin] clanged. Clock clacked. (XI - 254)

[onomatopaico]

Sparkling bronze azureeyed Blazure's sky-blue bow and eyes. (XI - 254)

Bronzedouce, communing with her rose that sank and rose... (XI - 254)

...Richie Goulding, Collis, Ward ate steak and kidney, steak then kidney, bite by bite of pie he ate Bloom ate they ate. (XI-258)

Obs.: /p/ é o equivalente surdo de /b/.

Boylan impatience, ardentbold. $(\mathrm{XI}-258)$

$[\operatorname{adj}(n)][\operatorname{adj}(\operatorname{adj}+\operatorname{adj})]$

Pat, waiter, waited, waiting to hear, for he was hard of hear by the door. (XI-261)

Tipping her tepping her tapping her topping her. Tup. (XI - 262)

Obs.: Seqüência vocálica completa, abrangendo das palatais às velares.

...joygush, tupthrob. (XI - 262)

$[n(n+n)][n(n+n)]$

...everywhere all soaring all around about the all, the endlessnessnessness... (XI -263)

[n(n + repetição dupla do sufixo para ênfase da infinitude)] 
- Bravo! Clapclap. Good man, Simon. Clappyclapclap. Encore! Clapclipclap clap. Sound as a bell. Bravo, Simon! Clapclopclap. Encore, enclap, said, cried, clapped all, Ben Dollard, Lydia Douce, George Lidwell, Pat, Mina Kennedy, two gentlemen with two tankards, Cowley, first gent with tank and bronze Miss Douce and gold Miss Mina. (XI - 264)

[onomatopaico; relação de nomes prolonga aplauso]

Pat is a waiter hard of his hearing. Pat is a waiter who waits while you wait. Hee hee hee hee. He waits while you wait. Hee hee. A waiter is he. Hee hee hee hee. He waits while you wait. While you wait if you wait he will wait while you wait. Hee hee hee hee. Hoh. Wait while you wait. (XI - 268)

Obs.: É claro que as aliterações com /h/ e /w/ são onipresentes se desconsiderarmos a repetição de blocos de texto.

...snakes hissss. (XI - 269)

[imitação do sibilar de uma cobra]

Croak of vast manless moonless womoonless marsh. (XI- 270)

['woman' + 'moonless']

...red rose rose slowly, sank red rose.

Heartbeats: her breath: breath that is life.

Obs.: Efeito notável!

Are you off? Yrfmstbyes. $(X I-273)$

['yes' dito enquanto se come]

Big Benaben Dollard. Big Benben. Big Benben. (XI - 274)

['Big Ben' + 'Ben Dollard']

Tap. Tap. Tap. Tap. (XI - 274)

[som de bengala]

Tap blind walked tapping by the tap the curbstone tapping, tap by tap. (XI - 275) 
Pwee! A wee little wind piped. Eeee. In Bloom's little wee. (XI - 275)

Obs.: Rima visual em 'piped'.

Under the sandwich bell lay on a bier of bread one lost, one lonely, last sardine of summer. Bloom alone. (XI - 276)

Obs.: O período Bloom alone é isolado do resto do parágrafo; também os sons e letras que compõem o nome 'Bloom', mostrados em companhia de diversos outros no período anterior e aqui isolados, enfatizam a presente solidão de Bloom!

Tap. Tap. A stripling, blind, with a tapping cane came taptaptapping by Daly's window where a mermaid, hair all streaming (but he couldn't see), blew whiffs of a mermaid (blind couldn't), smoke mermaids, coolest whiff of all. (XI - 276)

Obs.: Note-se em especial o jogo visual com $\mathbf{m}$ e w, opostos tipograficamente.

Pprrpffrrppffff. (XI - 278)

[onomatopaico]

The figure seated on a large boulder at the foot of a round tower was that of a broadshouldered deepchested stronglimbed frankeyed redhaired freelyfreckled shaggybearded widemouthed largenosed longeaded deepvoiced barekneed brawnyhanded hairylegged ruddyfaced sinewyarmed hero. (XII 283)

Obs.: Obedecem todas à seguinte estrutura: $[\operatorname{adj}(\operatorname{adj}+\mathrm{v}(\mathrm{n}-e d))]$. Note-se a ausência de pontuação.

Ga ga gara. Klook klook klook. Black Liz is our hen. (XII - 301)

[onomatopaico]

An exquisite ducet epithalame of most mollificative suadency for juveniles amatory whom the odoriferous flambeaus of the paranymphs have escorted to the quadrupedal proscenium of connubial communion. (XIX - 374)

Obs.: Período latinizado de 'Oxen of the Sun'. Guimarães Rosa também empregava com freqüência estruturas sintáticas e morfológicas de outras línguas.

Beer, beef, business, bibles, bulldogs, battleships, buggery and bishops. (XIV - 404) 
Come on, you winefizzling ginsizzling boozeguzzling existences! Come on, you doggone bullnecked, beetlebrowed, hogjowled, peanutbrained, weaseleyed fourflushers, false alarms and excess baggage! (XIV - 407)

[adj (n + v-ing)] [adj ('animal' $\mathrm{n}+\mathrm{n}-\mathrm{ed})<$ 'doggone']

Jest you try it on. (XIV - 407)

[pronúncia inculta de 'just']

...groans, grinding growling teeth... (XV - 408)

Bloom pats with parcelled hands watchfob, pocketbookpocket, pursepoke, sweets of sin, potato, soap. $(\mathrm{XV}-414)$

...plump as a pampered pouter pigeon. (XV-417)

Bald Pat, bothered beetle... (XV - 420)

Obs.: /p/ é o equivalente surdo de /b/.

Kaw kave kankury kake. (XV - 425)

Haw haw, have you the horn? (XV - 497)

Substituting Stephen for Bloom, Stoom...Substituting Bloom for Stephen, Blephen... (XVII - 595) 


\section{Bibliografia}

ABRAMS, Meyer Howard (ed.). The Norton anthology of English literature: major authors edition. New York, W.W.Norton \& Company, 1975.

AlighIERI, Dante. Inferno. Translated, with an introduction by John Ciardi. New York, The Modern Library, 1996.

AUBERT, Francis Henrik. As (in)fidelidades da tradução: servidões e autonomia do tradutor. Campinas, UNICAMP, 1994.

BASSNETT, Susan. Translation Studies. London and New York, Routledge, 1994.

BAYM, Nina. The Norton anthology of American literature. $4^{\text {th }}$ edition. New York, W. W. Norton \& Company, 1994.

Beowulf. Translated by Seamus Heaney. London, Faber and Faber, 1999.

Berman, Antoine. L'auberge du lointain. In: Berman, Antoine (ed.). Sur les tours de Babel. Mauvezin, Trans-Europ-Repress, 1985.

Blaisdell, Bob (ed.). Imagist poetry: an anthology. New York, Dover Publications, Inc., 1999.

Borges, Jorge Luis. Prosa completa. Barcelona, Bruguera, 1980.

BRoch, Hermann. A morte de Virgílio. Traduzido por Herbert Caro. São Paulo, Editora Mandarim, 2001.

Brown, Sally. The original Alice: from manuscript to Wonderland. London, The British Library, 1997.

CAmpos, Augusto de. O anticrítico. São Paulo, Companhia das Letras, 1986.

CAMPos, Haroldo de. Qohélet = O-que-sabe: Eclesiastes: poema sapiencial. Com uma colaboração especial de J. Guinsburg. São Paulo, Perspectiva, 1991. 
CANDIDO, Antonio. O estudo analítico do poema. São Paulo, Humanitas, FFLCH/USP, 1996.

Carroll, Lewis. Alice do Outro Lado do Espelho. Trad. Maria Filomena Duarte. Lisboa, Publicações Dom Quixote, 1988.

CARroll, Lewis. Alice in Wonderland. Authoritative texts of Alice's adventures in Wonderland, Through the looking-glass, The hunting of the snark, backgrounds, essays in criticism. Edited by Donald J. Gray. New York, W. W. Norton \& Company, 1992.

CARroll, Lewis. Alice's Adventures Under Ground. A facsimile of the 1864 manuscript. Introduction by Martin Gardner. New York, Dover, 1965.

CARroll, Lewis. The Complete Illustrated Lewis Carroll. With and introduction by Alexander Woollcott. Hertfordshire, Wordsworth Editions, 1998.

Castello, José. Fantasma. Rio de Janeiro, Record, 2001.

CoHen, Morton N. Lewis Carroll: a biography. New York, Vintage Books, 1996.

Contemporary English Version Newcomer Bible. London, HarperCollinsPublishers, 2000.

CUlleR, Jonathan. Literary theory: a very short introduction. Oxford. Oxford University Press, 2000.

Dickens, Charles. Oliver Twist. Tradução de Machado de Assis e Ricardo Lísias. São Paulo, Hedra, 2002.

DrIVER, Paul (ed.). Victorian Poetry. London, Penguin Books, 1996.

DUSINBERRE, Juliet. Alice to the lighthouse: children's books and radical experiments in art. Macmillan Press Ltd, 1999.

Eco, Umberto. Baudolino. Tradução de Marco Lucchesi. Rio de Janeiro, Record, 2001.

ELIOT, T. S. Selected Prose of T. S. Eliot. London, Faber and Faber, 1975.

FErguson, Margaret (ed.). The Norton anthology of poetry. Shorter $4^{\text {th }}$ edition. New York, W. W. Norton \& Company, 1997.

GENTZLER, Edwin. Contemporary translation theories. London, Routledge Inc., 1993.

GIFFORD, Don. Ulysses annotated. Revised and expanded edition. Berkeley, University of California Press, 1989.

Gincrich, F. Wilbur e Danker, Frederick W. Léxico do N.T. Grego/Português. São Paulo, Edições Vida Nova, 1983. 
Giovanni, Norman, Halpern, Daniel e Macshane, Frank (eds.). Borges on writing. New York, The Ecco Press, 1994.

GLEICK, James. Faster: the acceleration of just about everything. New York, Vintage Books, 1999.

GRAHAM, Eleanor. "How the story was told" and "Lewis Carroll and the writing of Through the Looking Glass" em CARroll, Lewis. Alice's Adventures in Wonderland and Through the Looking Glass. Middlesex, Puffin Books, 1981.

GraiEB, Carlos. "Os sem-estilo” em Veja, 6/3/2002.

GUERIN, Wilfred L. [et al.]. A handbook of critical approaches to literature. Oxford, Oxford University Press, 1999.

Hamilton, Edith. A mitologia. Lisboa, Publicações Dom Quixote, 1983.

JaKobson, Roman. Poética em ação. São Paulo, Perspectiva e EDUSP, 1990.

JoYCE, James. Ulysses. Edited by Danis Rose. London, Picador, 1998.

Kenner, Hugh. The Pound Era. Berkeley and Los Angeles, University of California Press, 1973.

La Bible de Jérusalem. Nouvelle édition revue et corrigée. Paris, Les Éditions du Cerf, 1998.

LEFEVERE, André. Translation, rewriting and the manipulation of literary fame. London, Routledge, 1992.

LENNARD, John. The poetry handbook. Oxford, Oxford University Press, 1997.

Martins, Eduardo. Manual de redação e estilo de O Estado de São Paulo. São Paulo, Editora Moderna, 1997.

Martins, Marcia A. P. (ed.). Tradução e multidisciplinaridade. Rio de Janeiro, Editora Lucerna, 1999.

Meschonnic, Henri. Pour la poétique II: Épistémologie de l'écriture/Poétique de la traduction. Paris, Éditions Gallimard, 1973.

Milton, John, (ed.). Modern Poetry from Brazil: Special Feature. In: WEISSBORT, Daniel, (ed.). Modern Poetry in Translation (New Series) 6. London, King's College London, 1994.

Milton, John, ed. Cadernos de Literatura em Tradução 3: Os Poemas Gregos de Antonio Medina. São Paulo, Humanitas, FFLCH/USP, 1999. 
Milton, John, ed. Cadernos de literatura em tradução 4. São Paulo, Humanitas, FFLCH/USP, 2001.

MiLton, John. "Condensation and translation" em Estudos Acadêmicos Unibero. Ano III Número 5 - Março/1997.

Milton, John. O Clube do Livro e a tradução. Bauru, EDUSC, 2002.

Milton, John. O Poder da Tradução. São Paulo, Ars Poética, 1993 (reeditado como Tradução: teoria e prática. São Paulo, Martins Fontes, 1998).

Ming Xie. "Pound as translator" in: the Cambridge Companion to Ezra Pound. Edited by Ira B. Nadel. Cambridge, Cambridge University Press, 1999.

New American Standard Bible-Update Edition. Grand Rapids, World Publishing, 1995.

New International Version. Grand Rapids, Zondervan Publishing House, 1978.

New Living Translation. Wheaton, Tyndale House Publishers, 1997.

New Revised Standard Bible. Grand Rapids, Zondervan Publishing House, 1990.

Novum Testamentum Graece. Nestle-Aland. 27. Revidierte Auflage. Stuttgart, Deutsche Bibelgesellschaft, 1993.

PereirA, Isidro, S.J. Dicionário Grego-Português e Português-Grego. Porto, Livraria Apostolado da Imprensa, sem data.

Pound, Ezra. ABC of reading. London, Faber \& Faber, 1979.

Pound, Ezra. Early Poems. New York, Dover Publications, Inc., 1996.

Pound, Ezra. Selected poems. London, Faber \& Faber, 1981.

Pudney, John. Lewis Carroll and His World. London, Thames and Hudson, 1976.

QUINTANA, Mário. Nova antologia poética. Rio de Janeiro, CODECRI, 1981.

Rienecker, Fritz e Rogers, Cleon. Chave Lingüistica do Novo Testamento Grego. São Paulo, Edições Vida Nova, 1970.

RODRIGUES, Cristina Carneiro. Tradução e diferença. São Paulo, Editora UNESP, 2000.

RosA, João Guimarães. Primeiras Estórias. Introdução de Paulo Rónai. Rio de Janeiro, Livraria José Olympio Editora, 1981.

SHIRTS, Matthew. "Literatura e dinheiro" em O Estado de São Paulo, 1/4/2002.

StOFFEL, Stephanie Lovett. Lewis Carroll and Alice. London, Thames and Hudson, 1997.

TAYLOR, W. C. Dicionário do Novo Testamento Grego. Rio de Janeiro, JUERP, 1980. 
TELUSHKIn, Joseph. The book of Jewish values: a day-by-day guide to ethical living. New York, Bell Tower, 2000.

The Amplified Bible. Grand Rapids, Zondervan Publishing House, 1987.

The E. W. Bullinger Companion Bible. Grand Rapids, Zondervan Bible Publishers, 1974.

The message: the Bible in contemporary language. Translated by Eugene H. Peterson. Colorado Springs, Navpress, 2002.

The Torah: the five books of Moses. Philadelphia, Jewish Publication Society, 1999.

VENUTI, Lawrence. The translator's invisibility: a history of translation. London and New York, Routledge, 1995.

WAKELING, Edward (ed.). Lewis Carroll's Games and Puzzles. New York, Dover, 1992.

Wells, H. G. A máquina do tempo. Recontado por Paulo Mendes Campos, Rio de Janeiro, Edições de Ouro, 1972.

Wells, H. G. Selected short stories. London, Penguin Twentieth-Century Classics, 1989.

WiLliams, Joseph M. Style: toward clarity and grace. Chicago and London, The University of Chicago Press, 1990.

WOLFREYS, Julian e BAKER, William (eds.). Literary theories: a case study in critical performance. London, MacMillan Press Ltd, 1996. 